Article

\title{
Land-Use Changes of Historical Rural Landscape-Heritage, Protection, and Sustainable Ecotourism: Case Study of Slovak Exclave Čív (Piliscsév) in Komárom-Esztergom County (Hungary)
}

\author{
Peter Chrastina ${ }^{1}$, Pavel Hronček ${ }^{2}$, Bohuslava Gregorová ${ }^{3}$ and Michaela Žoncová ${ }^{3, *}$ (D) \\ 1 Department of Historical Sciences and Central European Studies, Faculty of arts, University of Ss. Cyril and \\ Methodius Trnava, Námestie J. Herdu 2, 91701 Trnava, Slovakia; peter.chrastina@ucm.sk \\ 2 Department of Geo and Mining Tourism, Institute of Earth Resources, Faculty of Mining, Ecology, \\ Process Control and Geotechnologies, Technical University of Kosice, Němcovej 32, 04001 Košice, Slovakia; \\ pavel.hroncek@tuke.sk \\ 3 Department of Geography and Geology, Faculty of Natural Sciences, Matej Bel University in Banská Bystrica, \\ Tajovského 40, 97401 Banská Bystrica, Slovakia; bohuslava.gregorova@umb.sk \\ * Correspondence: michaela.zoncova@umb.sk
}

Received: 30 June 2020; Accepted: 22 July 2020; Published: 28 July 2020

check for updates

\begin{abstract}
The landscape surrounding the village of Čív (Piliscsév in Hungarian) in the north of the Komárom-Esztergom County is part of the cultural heritage of the Slovaks in Hungary. This paper discusses the issue of the Čiv landscape changes in the context of its use (historical land use). Between 1701 and 1709, new inhabitants began cultivating the desolated landscape of the Dorog Basin, which is surrounded by the Pilis Mountains. This paper aims to characterize the Slovak exclave Čív land use with an emphasis on the period from the beginning of the 18th century (Slovak colonization of the analyzed territory) to 2019. These findings subsequently lead to the evaluation of the stability of the cultural-historical landscape as an essential condition for the development of ecotourism in the cultural landscape. The study results show that a long-term stable cultural landscape has a similar potential for the development of ecotourism as a natural landscape (wilderness). Research conclusions were aimed at creating three proposals for the cultural landscape management of the study area, conceived by the fundamental pillars of ecotourism, which would lead to its stable and sustainable use in ecotourism.
\end{abstract}

Keywords: historical landscape; cultural landscape; land use; landscape stability; sustainability; ecotourism

\section{Introduction}

Land-use changes are a constant cycle around the world, whether due to natural, quasi-natural, or anthropogenic processes. They always depend on the size of the driving force that acts on the (historical) landscape-land-use in an earlier period (earlier developmental stage), i.e., how intensively it can cover older layers and to what extent the oldest historical landscape will be preserved in the given area. A cultural landscape is created in a given time horizon if the driving forces are anthropogenically influenced or if they are of anthropogenic origin. Consequently, we can consider the historical-cultural landscape to be stable or relatively stable, if the earlier driving forces are weaker, less intense, or even almost absent. Stable cultural landscapes created in the oldest possible history represent an essential heritage of human society, not only of regional but also of national or European importance.

The landscape of the Slovak exclave Čív (hun. Piliscév) in the northern part of the Komárom-Esztergom County, which is a part of the cultural heritage of Slovaks in Hungary, is an 
interesting example. The study presents the local landscape historical development issue in the context of its use (historical land-use) with specific forms that the Slovak ethnic group brought from the territory of their origin (ancestors). The researched landscape with elements preserved from the Roman Empire period, as an already abandoned landscape at the southwestern foothills of Piliš (hung. Pilis), began to develop from the first quarter of the 18th century. The development progressed in the process of changes initiated by the population of the Slovak ethnic group of Roman Catholic denomination from the Counties located north of the Danube.

The study is research into the issue of historical land-use in order to examine the land-use of Slovak exclave Čív from the beginning of the 18th century to 2019. The development of the local landscape's historical land-use after the arrival of Slovak colonists is shown on five thematic maps (from the years 1782-1785, 1841, 1882, 1941, and 2019), a table with areas of land-use classes (LUC), and a diagram. Research results are supplemented by a framework proposal for the management of the local landscape to preserve or adapt its character and values to ecotourism development in the historical-cultural rural landscape.

Geographers and landscape ecologists primarily address the issue of long-term landscape changes or its specific components; e.g., Fescenko, Nikodemus, and Brūmelis [1] reconstructed changes in spatial patterns of forest area during the last 220 years in an agricultural matrix of Zemgale region (Latvia). Olah, Boltižiar, and Gallay [2] analyzed the Slovak landscape (since the 18th century) and its current trends on the example of 16 model areas. Fialová, Chromý, and Marada [3] studied the development of the Vltava riverbanks' functional use in Prague. The work of Trpáková [4] represents a landscape ecologist point of view on the dynamics of landcover changes in the model areas Sokolovsko, Kladruby nad Labem, and Novodvorsko-Žehušicko in the Czech Republic. Wang et al. [5] prepared an analysis of land-use changes related to invasive species from 1996 to 2006 and predicted land-use and landcover changes to 2018, while they also characterized the significant driving forces in the State of Connecticut (USA).

M. Boltižiar, P. Chrastina, and J. Trojan [6], P. Chrastina [7-9], P. Chrastina and M.Boltižiar [10,11], P. Chrastina et al. [12], P. Chrastina, J. Trojan, and P. Valášek [13], and P. Chrastina, K. Křováková, and V. Brůna [14] applied an integrated (interdisciplinary) approach to the historical land-use of Slovak exclaves in Hungary, Romania, and Serbia.

The cultural landscape is increasingly becoming an object of interest for visitors, especially in the intensively economically developed countries of Europe. It has the potential for developing various types of tourism, including ecotourism.

This type of tourism has emerged since the 1970s. It is a very pure form of tourism in terms of the impact on the environment and the population of the local region. Its primary feature is the sustainability and adequacy of the given conditions of the landscape concerning the stability of existing ecosystems and the use of available natural resources. This form of tourism is currently still perceived rather restrictively in terms of economic activities. Ecotourism is only fulfilled substantially by the understanding of the relationship of man and nature and the perception of man as part of the landscape. Ecotourism emphasizes the local population and the local landscape and provides visitors with the natural or cultural heritage of the chosen destination. Being impact-less to the landscape to which they are heading is essential for ecotourists. Therefore, respect for the local landscape, different lifestyles, nature, or culture are the key concepts.

The concept of ecotourism began to become gradually domesticated in the 1980s. Subsequently, the International Ecotourism Society formulated the first generally accepted basic definition of ecotourism: "Responsible travel to natural areas that conserves the environment and improves the well-being of local people" [15]. This initial definition is the backbone of the study of ecotourism and remains a valid concept in general, also from a broader perspective of experts who consider ecotourism as any form of environmentally friendly tourism. With a more precise definition of the term, ecotourism is a form of tourism that contributes to natural resources protection. The abovementioned definition 
is a base for experts specializing in ecotourism around the world. Table 1 provides selected basic definitions of ecotourism from experts and institutions from different regions of the world.

Table 1. Overview of selected definitions in chronological order, based on the initial definition of ecotourism as responsible travel to natural areas that conserves the environment and improves the well-being of local people.

\begin{tabular}{cc}
\hline Source & Definition \\
\hline Ziffer (1989) [16] & $\begin{array}{c}\text { A form of tourism inspired primarily by the natural history of an } \\
\text { area, including its indigenous cultures. The ecotourist visits } \\
\text { relatively undeveloped areas in the spirit of appreciation, } \\
\text { participation, and sensitivity. The ecotourist practices a } \\
\text { non-consumptive use of wildlife and natural resources and } \\
\text { contributes to the visited areas through labor or financial means } \\
\text { aimed at directly benefiting the conservation of the site and the } \\
\text { economic well-being of the local residents. }\end{array}$ \\
Brandon (1996) [17] & $\begin{array}{c}\text { Environmentally responsible travel and visitation to relatively } \\
\text { undisturbed natural areas, in order to enjoy and appreciate nature } \\
\text { that promotes conservation, has low negative visitor impact, and } \\
\text { provides for beneficially active socio-economic involvement } \\
\text { of local populations. }\end{array}$ \\
\hline Honey (1999) [18] & $\begin{array}{c}\text { Travel to fragile, pristine, and usually protected areas that strive to } \\
\text { be low impact and (usually) small scale. It helps educate the } \\
\text { traveler; provides funds for conservation; directly benefits the } \\
\text { economic development and political empowerment of local } \\
\text { communities; and fosters respect for different cultures and for } \\
\text { human rights. }\end{array}$ \\
\hline
\end{tabular}

Interest in ecotourism, now widespread among tourism planners and marketers, is rationalized by a number of popular assumptions Weaver (1999) [19] regarding the sector's potential economic, environmental, and socio-cultural benefits. Ecotourism is a form of tourism that fosters learning experiences and appreciation of the natural environment, or some component thereof, within its associated cultural context.

Ecotourism as a very specific form is part of the broad concept of

Weaver (2008) [20] nature-based tourism, or it can be said that ecotourism describes a nature-based operation in the field of tourism. "The most obvious characteristic of Ecotourism is that it is nature based".

Ecotourism is travel resp. a visit of areas of natural value and

Kurek et al. (2008) [21] conservation for the purpose of exploring them, while respecting the principles of protection of the visited areas and their ecosystems and the integrity of the local community.

It focuses primarily on experiencing and learning about nature, its landscape, flora, fauna and their habitats, as well as cultural

Rahman (2010) [22] artifacts from the locality. A symbiotic and complex relationship between the environment and tourist activities is possible when this philosophy can be translated into appropriate policy, careful planning and tactful practicum.

Ecotourism is now defined as "responsible travel to natural areas that conserves the environment, sustains the well-being of the local people, and involves interpretation and education".

The International Ecotourism Society (2015) [23] Education is meant to be inclusive of both staff and guests.

Responsible travel to natural areas that conserves the environment, socially and economically sustains the well-being of the local people, and creates knowledge and understanding through interpretation and education of all involved.

Global Ecotourism Network (2019) [24]

The business of organizing holidays to places of natural beauty in a way that helps local people and does not damage the environment.

The issue of ecotourism in general, e.g., [15-17,20,26-30], and the sustainability of ecotourism, e.g., [31-34], is currently being studied by a number of authors.

According to the given definitions, ecotourism as a new progressive global type of tourism stands (respectively stood) on three pillars of sustainability—environmental, social, and economic [35]. 
Ecotourism understood in this way would be sustainable only in those areas of the world where the wilderness, or the least anthropogenically impacted landscape, is still prevailing today. In areas with dominating cultural landscape, ecotourism perceived in this way would not be able to find its fulfilling application. However, people surrounded by modern (digital) civilization in the globalizing present are looking for an escape into areas with a stabilized cultural landscape with several tangible and intangible cultural (technical) monuments. This trend is starting to apply mainly in Europe, but also in other parts of the world (e.g., in Southeast Asia [36]), where the human civilization has left a reflection in the (natural) landscape since prehistory, but mainly since ancient times.

The idea of shifting the position of sustainable ecotourism to four pillars, i.e., environmental, social, economic, and cultural, is beginning to appear in the works of experts in ecotourism in Europe from the 90s of the 20th century, e.g., in France [37,38], Germany [39,40], Finland [41,42], Croatia [43], Greece [35], Russia [44,45], Romania [29], Scotland [46,47], and Turkey [48,49].

The cultural pillar is an important component of ecotourism in the region of Southeast and East Asia, e.g., [50-52], and Latin America napr. [19,53].

Theoretical and methodological issues of the cultural component (cultural landscape and cultural monuments) in ecotourism were described in the works of Wallace and Russell [42], Donohoe [35], and Campbell [46].

Experts in tourism in Central Europe began to address ecotourism later than the World Scientific Forum. Due to the nature of the landscape in this geographical area, where the cultural landscape significantly dominates, and the natural landscape (wilderness) has been preserved only in the form of relics of small protected areas, ecotourism in the original view of the three pillars would be challenging to develop in practice. In the area of the Western Carpathians, national parks and large protected areas are mostly not wilderness but a cultural landscape (e.g., Duna Ipoly Park in Hungary, Low Tatras National Park, Tatra (s) National Park, Vel'ká Fatra National Park in Slovakia and Užanskyj nacional'nyj pryrodnyj park in Ukraine). Therefore, experts have begun to understand sustainable ecotourism in terms of the four pillars, while the cultural pillar is often more important than the environmental (often the only one, because the wilderness is absent). The state and understanding of the issue are also pointed out by the very definitions of ecotourism by experts from Central Europe, or slightly more precisely from the Western Carpathians countries. Hungary: Ecotourism is the environmentally responsible travel and visiting of relatively unspoiled natural areas to please and appreciate their natural as well as current and past cultural values, which preserve them by mitigating the effects of the visit and bringing social and economic benefits to the local population [54]. Ecotourism is a form of tourism, or an alternative form of tourism, which is the opposite of its mass form. It emphasizes the importance of the environment and its cultural component, as well as their protection. Sustainability is an essential feature of ecotourism [55]. Slovakia: Ecotourism is a form of tourism in which tourists, individually or in small groups, visit attractive places that are little-known from a human point of view, whether it is their natural environment or cultural component in a tangible or intangible form [56]. According to B. Gregorová, [57] the co-author of this study, ecotourism is a form of tourism associated with wandering the landscape ("natural" and cultural) and observing, while gaining an authentic experience of learning about nature, as well as local communities and their culture. It develops sustainably; therefore, it minimizes negative impacts on the natural, social, and cultural environment to preserve the natural and cultural diversity and identity of the landscape. It is more economically efficient concerning local communities (rural settlements), despite its non-mass character, as it is provided by local service providers. Czech Republic: Ecotourism is wandering through nature (landscape), and its observation is developing mainly in areas with valuable landscape and nature. It supports natural areas, host communities, and nature conservation authorities. It provides local communities with alternative earning opportunities and raises awareness following the protection of the landscape's natural and cultural values [58]. Ecotourism is a type of tourism that focuses primarily on exploring natural beauty in terms of nature reserves, national parks, protected landscapes, and other natural attractions, intending to ensure that these attractions are not disturbed by tourism. In addition to 
natural heritage, it also focuses on cultural heritage and its protection. Poland: Ecotourism is an active exploration of valuable tourist attractions of natural and cultural character with intense emotional contact individually or in small groups. Adaptation to local communities, traditions, and culture is essential [59].

The research and the presented study aim to evaluate changes in land-use and stability of the historical (cultural) rural landscape from the beginning of the 18th century until 2019. It was an essential precondition for its preservation and protection in terms of historical heritage necessary for sustainable ecotourism. The researched historical rural landscape represents a cultural heritage as an essential specific element of the Slovak ethnic group living in a landscape inhabited by the dominant indigenous Hungarian population of the then Hungary.

At the same time, our effort is to present Central Europe's cultural landscape as a type of territory suitable for the development of ecotourism, which is currently carried out on relics of the original wilderness protected in the form of large or small protected areas. We also want to point out that the sustainable historical-cultural rural landscape of the Slovak exclave (village and its surroundings) of Čív (in the Dorog Basin) can develop this form of tourism.

We have to note here that the current landscape of Europe, particularly Central Europe, is made up almost exclusively of cultural landscapes, and even the national parks of the Carpathian arch protect mostly the historical-cultural landscape. Directing ecotourism only into the wilderness is problematic in this geographical area, although this type of landscape is a priority for ecotourists. A stabilized historical (rural) cultural landscape could also be a potential replacement for the unpreserved wilderness.

\section{Materials and Methods}

\subsection{Study Area}

The territory of Čív with an area of 2490 ha is located approximately $10 \mathrm{~km}$ south-southeast of Esztergom, in the Komárom-Esztergom County in the northern part of Hungary (Figure 1). The defined research area of 1771.5 ha lies in the central part of the cadastral area in the core settlement vicinity. The reason for this definition of the research area was the fact that the boundaries of the village were definitively constituted only in the 19th century. Therefore, the study of Čiv's land-use and its changes in the earlier periods would not be correct. The choice of the quadrilateral shape of the model area is a proven methodology used by, e.g., Kolejka [60] (pp. 148-151) in the study of landscape changes of the water reservoir Nové Mlýny in the Czech Republic, Gobin, Campling, and Feyen [61] (p. 215, 217) in the study of agricultural aspects of land-use of the city of Ikem in southeastern Nigeria, resp. Kuplich, Freitas, and Soares [62] (p. 2102) in the land-use classification of the city of Campinas in Brazil. The maps of land-use in the Tatras in the Atlas of representative landscape types of Slovakia [63] (pp. 166-167) or transects of the development of Corine Land Cover classes in the Atlas of land cover changes in selected European countries [64]. P. Chrastina et al. [12] also used the same methodology of delimitation of the territory to evaluate the historical land-use of the Tardoš settlement in Hungary.

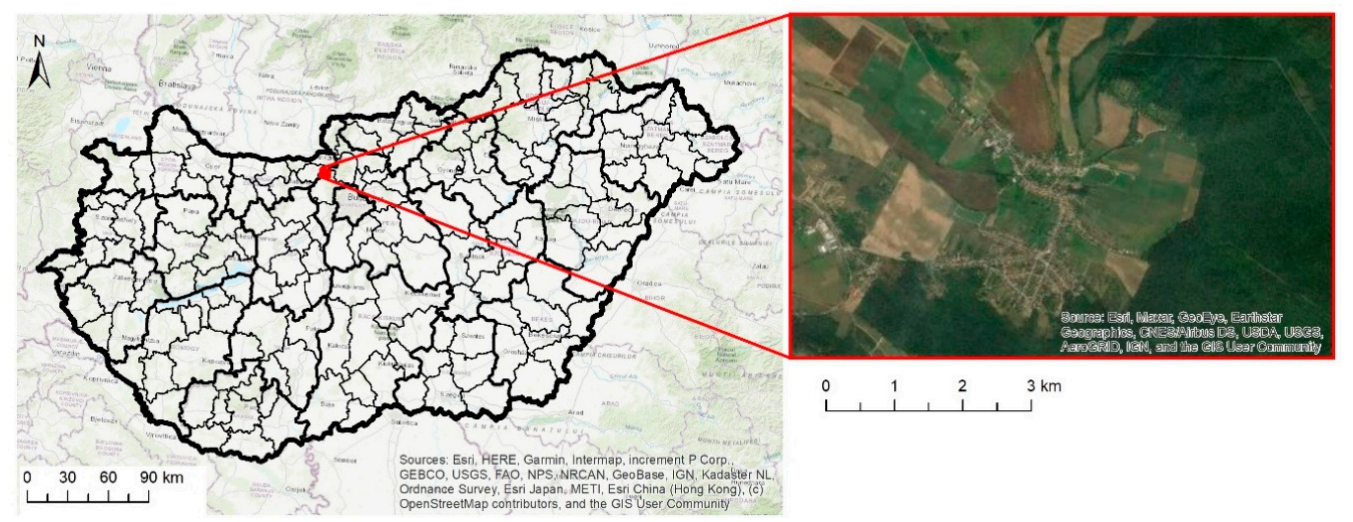

Figure 1. Location of the examined area. 
The Dorog Basin (hung. Dorogi-medence), built of sands, loess, and loess clays, occupies most of the area. The Piliš Mountains (hung. Pilis), part of the Dunazug Mountains, belong to the Transdanubian Central Mountains (hung. Dunántúli-középhegység), which is formed by limestone and dolomite rocks [65] (pp. 147-148). The studied area's altitudes range from about $163 \mathrm{~m}$ (floodplain of the Čív brook in the northwest of the area) to $418 \mathrm{~m}$ (Barina hill, or Barány-hegy). The erosion-denudation georelief of the Dorog Basin has a hilly character with steeper slopes and valleys (Figures 2 and 3).

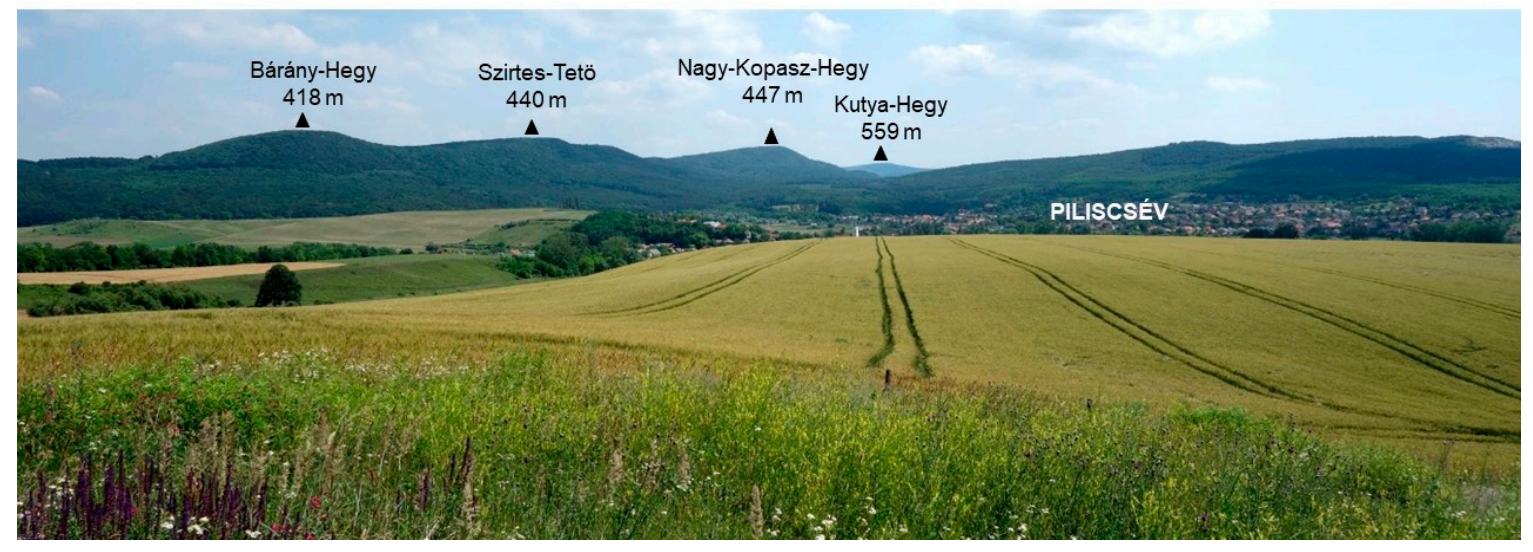

Figure 2. Location of Čív in the Dorog Basin. View from the north from Tatarské salaše hill (246 m above sea level) Author: P. Chrastina.

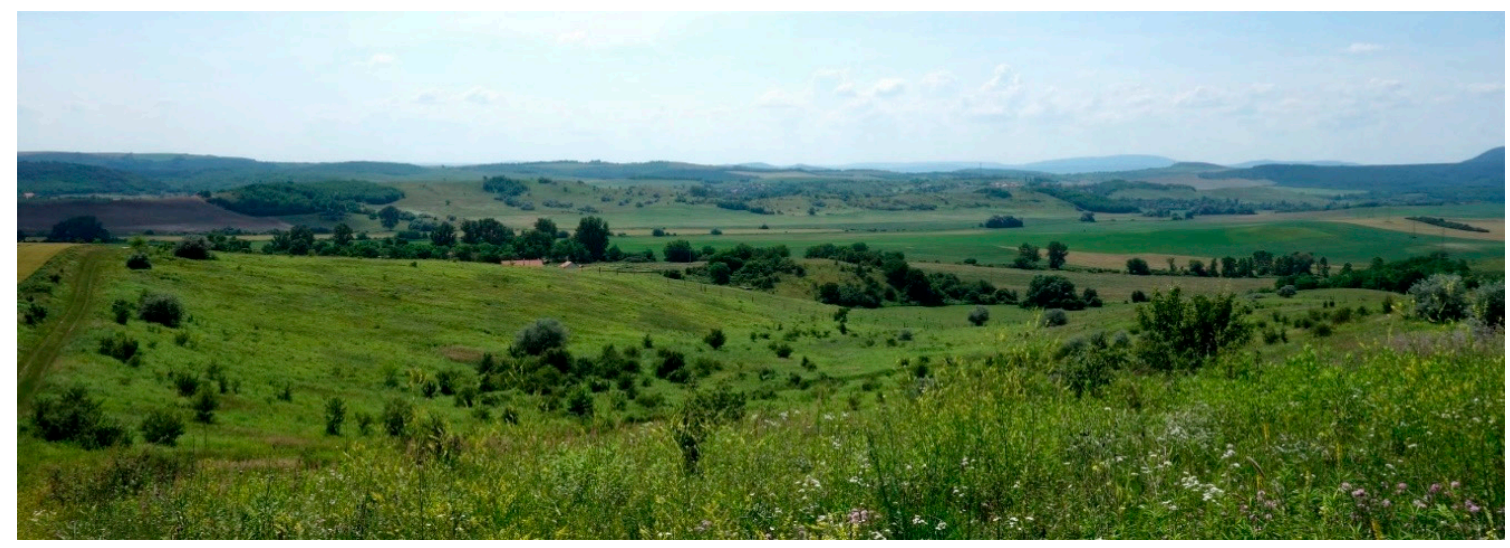

Figure 3. The Dorog Basin from Tatarské salaše hill (246 m above sea level). Author: P. Chrastina.

A warm, slightly dry to dry climate with annual total precipitation of up to $600 \mathrm{~mm}$ is typical for the studied area. The average annual temperature is around $10^{\circ} \mathrm{C}$. The Piliš Mountains belong to a warm mountain climate with a small temperature inversion and annual total precipitation of 800 to $1000 \mathrm{~mm}$ [66] (p. 240, pp. 242-243). Northwestern windflows significantly dominate during the year.

Soil types in the basin part of the area represent brown soils developed on loess and loess clays. The bottom parts of the damp, summer-drying valleys are covered with low-fertile pseudogley. Areas of regosols were created on areas of windblown sands at Homoki and Plešina sites in the south, resp. southwest of the study area. Fluvisols and gleys developed on the floodplain of the Čív brook (hung. Csévi Patak). Rendsinas on permeable limestones and dolomites cover the forested slopes of the Piliš Mts.

The original primeval forests in the basin part of the studied area consisted mainly of thermophilic Pontic-Pannonian oak forests on loess and sand [67] (pp. 10-11), [68] (pp. 93-94). On the slopes of the Piliš Mts. with rendzinas grew grassy oak forest [67] (p. 30). The wet floodplain of the Čiv Brook and the adjacent areas were potentially covered by lowland floodplain forests (Ulmenion Association) and wetland alder enclaves [67] (p. 14). 


\subsection{Methods}

The methodological procedure, research methods, and the elaboration of the study were divided into several directly related and concurrently implemented steps or stages, which systematically led to the fulfillment of the research goal and the processing of its results into the original scientific work (Figure 4).

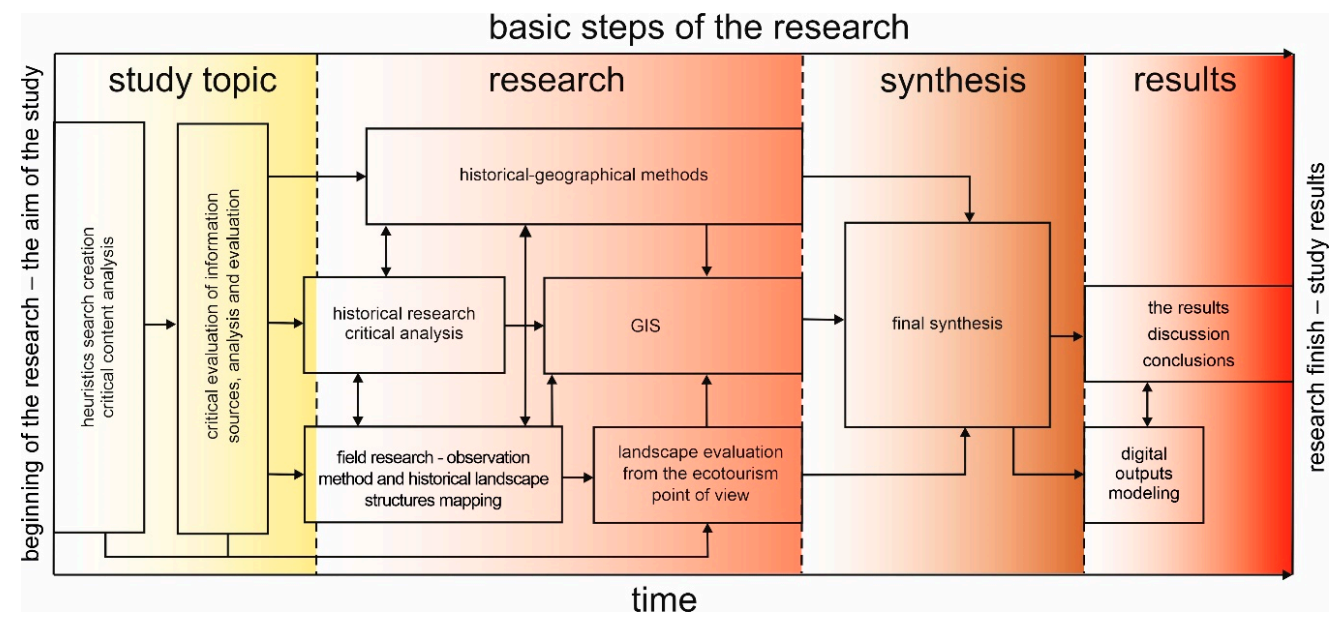

Figure 4. Schematic representation of theoretical and methodological procedures of the research and works. Source: authors' research.

The information database heuristics, the critical analysis of archival and literary sources was the basis, which led to the creation of a search on the researched topic using the bibliometric method [69-71].

Following the results of literary sources critical content analysis and the results of historical and field research, we used a combination of a range of evaluation, comparison, and synthesis methods [72]. As part of the synthesis of the results, we made proposals of the country's management to maintain its stability for the development of ecotourism.

Historical and field research. An essential step in elaborating the topic were the methods of historical research, especially critical analyses of historical sources, and the deductive and comparative-historical method. Following the historical research, we continued in the summer of 2019 with comprehensive field research of the historical landscape [73-80]. The preparation of the author's photo documentation was also a part of the field research.

Map data search, identification, content analysis, georeferencing, and vectorization. Cartographic sources consisted mainly of medium-scale maps (Table 2).

Table 2. Cartographic sources, their characteristics and sources.

\begin{tabular}{|c|c|c|c|c|}
\hline Designation of the Map Base/Source & $\begin{array}{l}\text { Map Sheet } \\
\text { Number }\end{array}$ & Scale & $\begin{array}{c}\text { Year of } \\
\text { Production }\end{array}$ & Source \\
\hline $\begin{array}{l}\text { I. military mapping, Theil des Pester } \\
\text { und Graner Comitat }\end{array}$ & $\begin{array}{l}\text { Coll. XIII. } \\
\text { Sectio XIX. }\end{array}$ & 1: 28,800 & $1782-1785$ & https://mapire.eu/en/ [81] \\
\hline $\begin{array}{c}\text { II. military mapping, } \\
\text { Königreich Ungarn, } \\
\text { District diesseits der Donau, Comitat } \\
\text { Gran. Honth. Pesth.; District jenseits - } \\
\text { diesseits der Donau, Comitat Komorn. } \\
\text { Gran. Pesth. }\end{array}$ & $\begin{array}{c}\text { Section } 48 . \\
\text { Colonne XXXI. } \\
\text { Section } 49 . \\
\text { Colonne XXXI. }\end{array}$ & 1: 28,800 & 1841 & https://mapire.eu/en/ [81] \\
\hline III. military mapping & $\begin{array}{l}4961 / 2 \\
4962 / 1\end{array}$ & 1: 25,000 & 1882 & https://mapire.eu/en/ [81] \\
\hline Topographic map of military mapping & $?$ & 1: 75,000 & 1941 & https://mapire.eu/en/ [81] \\
\hline Orthophoto (satellite image) & - & $\begin{array}{c}\text { cca } \\
1: 75,000\end{array}$ & (24. 3.) 2019 & Google Earth [82] \\
\hline
\end{tabular}


The I. to III. military mapping maps were taken from the Military Historical Archive in Budapest (Hadtörténelmi Levéltár). The military map from 1941 was obtained digitized (online) from the Mapire web application [81]. According to G. Timár et al. [83,84], resp. G. Timár and S. Biszak [85], the initial georeferencing procedure was realized into the WGS84 coordinate system. Maps were reprocessed into the HD72/EOV coordinate system (EPSG 23700) as part of the digitization itself, in which the area was quantified (calculated) as well. A digital satellite image from Google Earth Pro from 2019 was modified analogously (Figure 5).
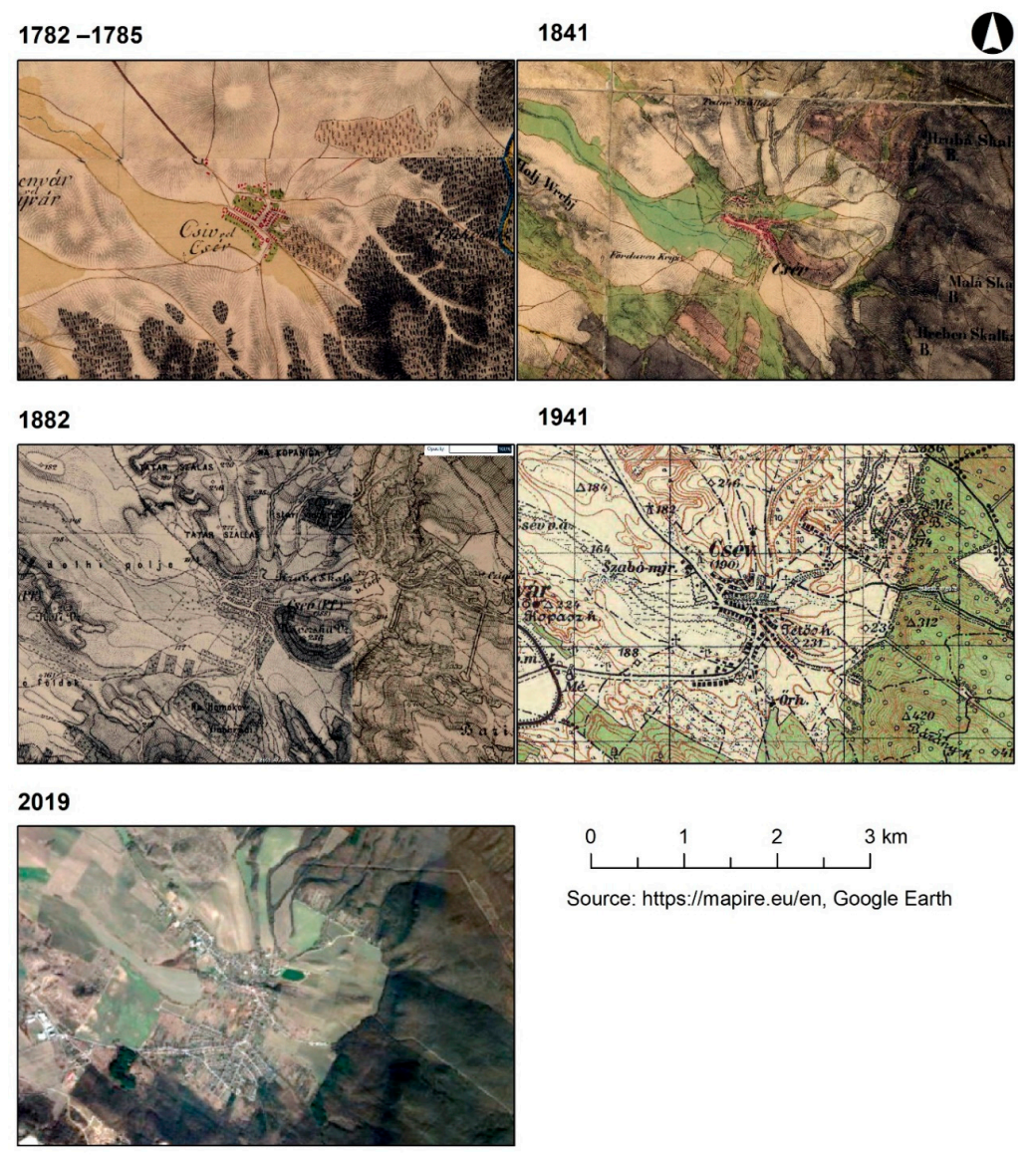

Figure 5. The researched area on historical maps in selected time horizons.

A mask (rectangular section) was created around the built-up area of Čív for the correct comparison of the sections of the examined area, as stated in the previous part of the study. This mask was also applied to digitize the selected areas to perform their comparative analysis (Figure 5).

\section{Comparative Analysis of Cartographic Data}

The areas of land-use classes (LUC) with line layers of watercourses and roads were interpreted on each of the georeferenced digital maps using geographic information systems (QGIS3). The final product of the comparative analysis is represented by large-scale maps of historical land-use $(1: 25,000)$, depicting the land-use of the studied area in the relevant period [86-88].

The scales of most cartographic data and satellite imagery were smaller than the resulting classification of land use on thematic maps. Therefore, their content was generalized. The military map from 1941 and the satellite orthophoto image (2019) had the highest degree of content generalization.

The multitemporal analysis consisted of the LUC dynamics study in the QGIS3 environment. Specifically, it evaluated the development of LUC areas in the period given by the presentation of a map or satellite image and the subsequent statistical processing (numerical and graphical analysis). 
Interpretation of the historical land use development as an input matrix for evaluating the stability of the historical landscape with use for ecotourism. Framework proposals determination for the management of the cultural landscape of the studied area aimed at its protection (stabilization, preservation) as a historical heritage necessary for the development of sustainable ecotourism.

\section{Results}

\subsection{Prehistorical and Historical Land Use of the Čiv Landscape}

The initial human interventions in the local landscape occurred in the Eneolithic period (3500-2900 BC) [89]. Therefore, it is probable that the first deforestation of the original oak forests growing on brown soils, which man transformed into a mosaic of fields and pastures with islands of forests, took place in the Dorog basin already in the middle of the fourth and the early third millennium B.C.

In Roman times (around 1 A.D. -375/380, respectively 400 A.D.) the small fortress (kastel) Lacus Felicis lay on the territory of the village [90] (pp. 21-22), which protected the road leading from Brigetio through the territory villages to Aquincum (now Budapest). Remains of a watchtower with a defensive ditch (burgus), which were probably built during the reign of Emperor Valentinian I. (364-375 A.D.), were discovered in the locality Margeta (the northeast part of the studied area). Another monument from this period [89] (p. 30) is a torso of a stone-paved road in the southwest of the village at the Hosszú-rétek II. site, as well as two road milestones.

The economic activities of the Romanized population marked the landscape structure of the studied area, thanks to which the then landscape roughly resembled the current cultural landscape of Čív. The dry localities of the basin were occupied by fields intersected with roads with milestones and military architecture (burgus, potentially also a kastel). Settlements of members of higher social classes with a residential and economic function (so-called villa rustica) were scattered on agricultural land. The vineyards covered slopes with "warm" exposure. The wetland localities in the basin were characterized by a mosaic of extensive meadows and pastures, wetlands with reeds, and enclaves of floodplain forests or wetlands with alders. The deforested edges of the Piliš mountain slopes served potentially as meadows and pastures, but the steep slopes remained forested.

During the Mongol (Tatar) invasion into Hungary (1241-1242 A.D.), their military units allegedly camped at the Tatarské salaše hill [91] (p. 18) After the departure of the Mongol army, which conquered and burned the town of Esztergom in 1242 A.D. (the castle defended itself), the local settlement was decimated, and the areas of agricultural land were overgrown for about a decade. At the same time, the deforested foothills of Piliš were regenerated.

The territory of today's village belonged to the monarch in the second half of the 13th century, but the Esztergom Chapter had already owned the entire property in 1418 [92] (p. 15). The LUC mosaic in the basin part consisted of pastures with islands of non-forest woody vegetation and small fields. Extensive cattle breeding and farming works were performed by subjects from the surrounding villages of Kestúc (hung. Kesztölc) and Alberth [89] (p. 14).

The continuous development of the studied area's cultural landscape was interrupted at the beginning of the Modern Age. Most of the villages in the Dorog Basin were burned down by the Turks from 1526 to 1543 . Written sources from 1564 and 1570 prove that the area of today's Čív has become a wasteland, a depopulated area [92] (p. 16), [89] (p. 16).

The economic renewal was made possible by Esztergom's (1685) and Buda's (1686) liberation from the Turks and the conclusion of the Peace of Karlovac (1699). The first settlements of Slovak colonists in the studied area were established in the years 1701 to 1709 [93] (p. 77). The migration of settlers on the Esztergom Chapter's lands caused the later constitution of the village (around 1720). The inhabitants of Vel'ký Čív (hung. Nagy Csév) were Slovaks and Catholics from the territory of today's western Slovakia; based on the research of the Ćiv dialect [89] (p. 35), we can assume that they came mainly from the Nitra County and southern areas of the Trenčín County. 
Some of the colonists dealt with extensive cattle breeding on pastures. The others devoted themselves to agriculture. The fields on the clay-sandy and sandy-clay brown soils were formed mainly in the dry valleys and erosion-free slopes of the basin hills with a smaller slope. The local plow farms farmed with a two-field system provided up to three times the yield in 1715 [93] (p. 77). The vineyards of south slope of Stari vinohrad hill were established after the deforestation of the slope of the basin uplands in 1712; the vineyards on the southern slope of Vršek (or Na Vršku) hill are probably younger. A church dedicated to the Virgin Mary, Queen of Angels, was built in the middle of the village, at the foot of Vršek hill around the same time (the early 18th century).

Visual reconstruction of prehistorical and historical land use of the Čív landscape in the geographical area of the Dorog basin is clearly presented in the author's scheme of the spatio-temporal axis (Figure 6).

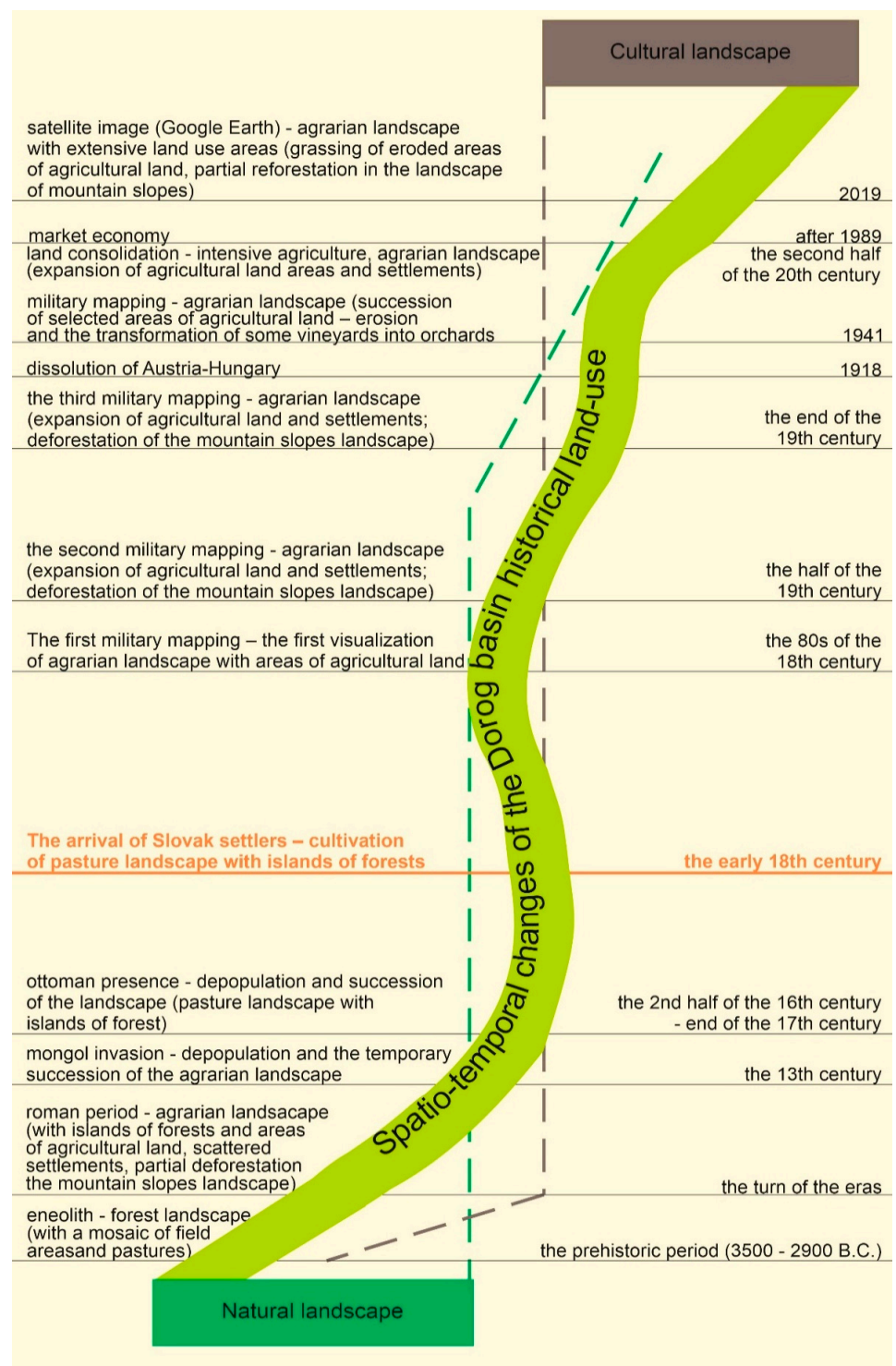

Figure 6. The graphic shows the visual axis of the main historical events in the geographical area of the Dorog Basin, which affected the natural landscape in terms of its spatio-temporal changes aimed at the emergence of the (current) cultural landscape. The distances between the lines of historical events represent their impact on the landscape, instead of time. The bigger the distance between the lines of events, the more intense their impact is on the transformation of the contemporary landscape. Source: authors' research. 
In 1732, Vel'ký Čív had 236 adults, of which were 26 peasants and 12 cotters [89] (p. 17), [92] (p. 18). The Theresian land-register from 1768 provides a general view of the representation of specific LUCs and the intensity of land-use in the studied area in the late 1960s [94] (pp. 263-265). During this period, the name of the village was Čív (hung. Csév). The document in Čív states 59.75 peasant settlements with an area of approximately 7000 ha. A total of 128 heads of families lived in the village in 1767.

They grew vineyards, cabbage, hemp, corn in larger areas, and fruit in the home gardens. The vineyards were located near the village at Vršek, or Na vršku hill, and further from the village at the Stari vinohrad hill. Plowlands and meadows further formed the landscape. A grain mill operated on the Čív Brook, which had very little water.

There was plenty of quality construction and firewood in the surrounding forest. The forest cover of the studied area fell below $40 \%$ during this period. The erosion of arable land in the sloping terrain of the basin and at the foot of Piliš Mts. was a disadvantage.

\subsection{Visualization and Quantification of Changes in the Historical Land-Use of the Studied Rural Landscape}

The origin, or, more precisely, the anthropogenic transformation of the natural landscape into a cultural landscape in space and time must be understood in the interaction of both characteristics. The research needs to choose a historical landscape at a specific time horizon and emphasize its stability, development, and changes compared to the previous period, which are visualized by the authors' scheme (Figure 7), whose time horizons can be imaginarily identified with the selected stages in the years 1782 to 2019 in the area.

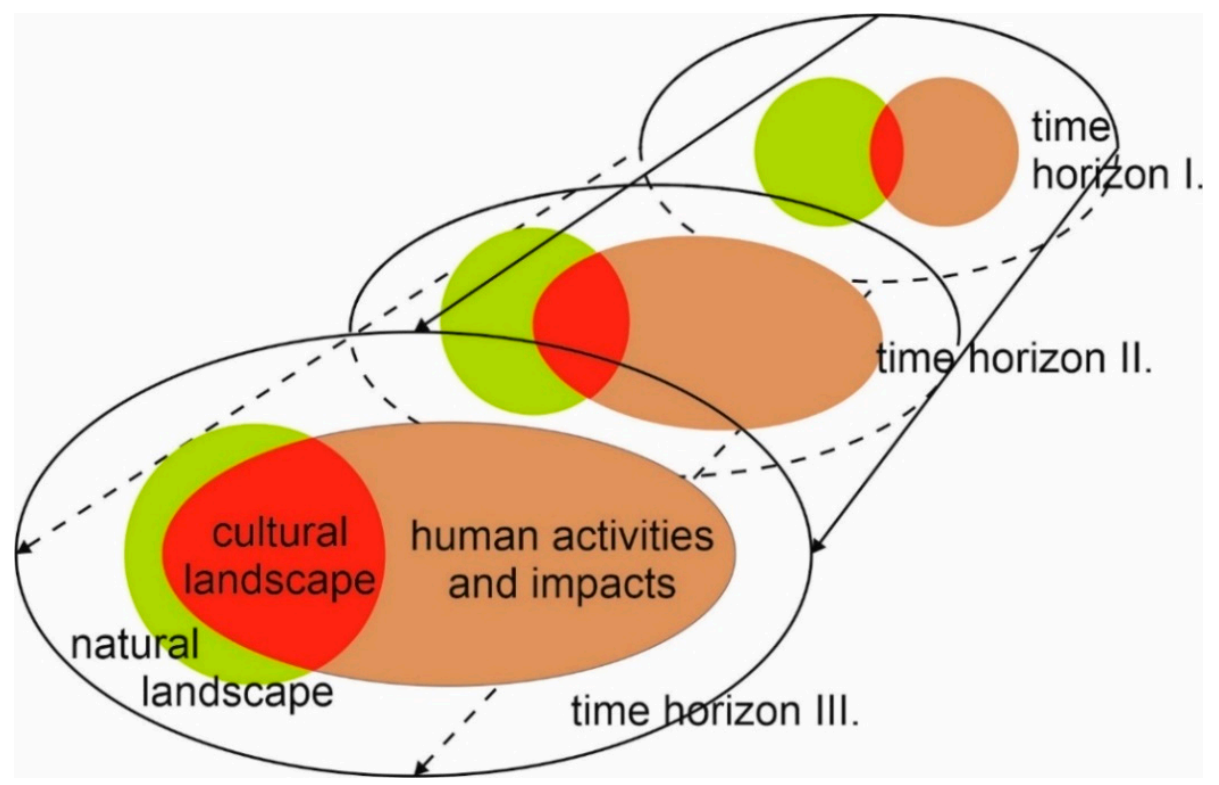

Figure 7. Visualization of man and the natural landscape interaction in time (in different time horizons) leading to the expansion (respectively to the emergence) of the cultural landscape and the defined (researched) territory. Source: authors' research

The visualization of land-use changes in the studied area from 1782-1785 to 2019 was processed using computer digitization. The results are presented in digital "map" outputs from the time horizons in question (Figure 8). The results of land-use dynamics changes and their quantification in these time horizons are presented in Table 3 and Figure 9. The analysis of the obtained results allows a detailed discussion and conclusions leading to the use of historical rural cultural landscapes in ecotourism. 
$1782-1785$

1841

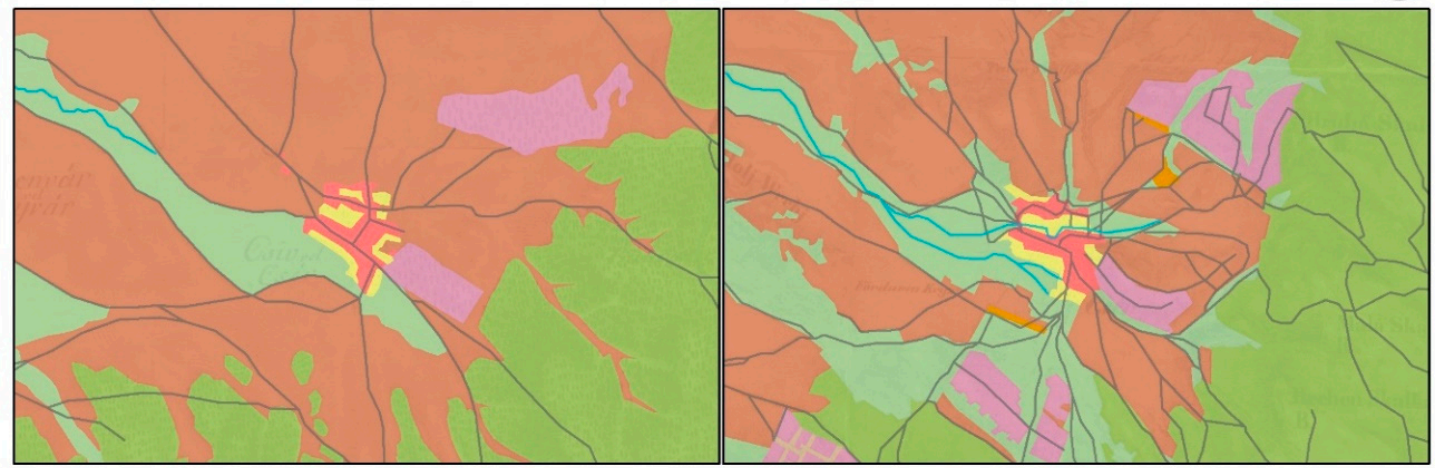

1882

1941

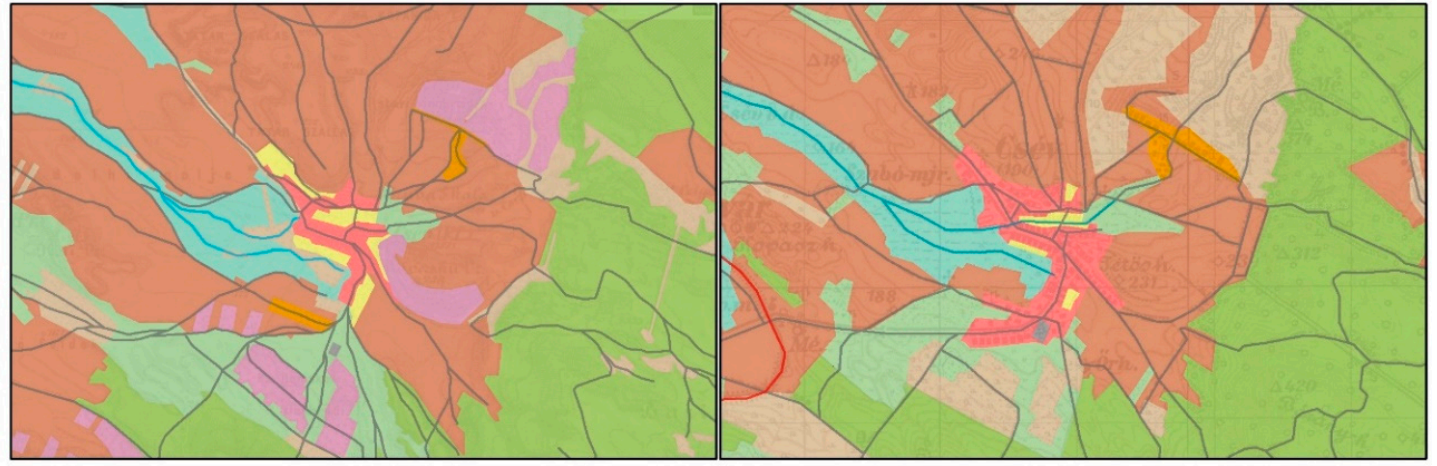

\section{9}
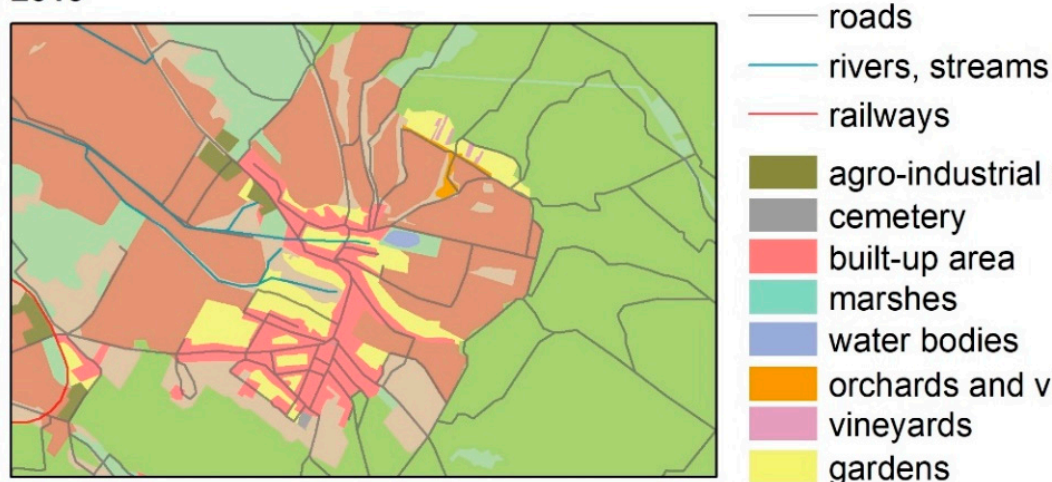

railways

agro-industrial areas
cemetery

built-up area

marshes

water bodies

orchards and vineyard huts

vineyards

gardens

arable land

permanent grasslands

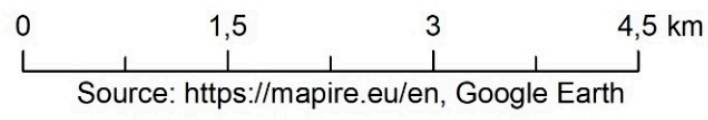

woodland and shrubs

forest

Figure 8. Computer visualization of the historical land use of the studied area in selected time horizons. 
Table 3. Development of land use classes (LUC) of the studied area in the years 1782/1785-2019.

\begin{tabular}{ccccccccccc}
\hline \multirow{2}{*}{ Land Use Classes (LUC) } & \multicolumn{2}{c}{$\mathbf{1 7 8 2 - 1 7 8 5}$} & \multicolumn{2}{c}{$\mathbf{1 8 4 1}$} & \multicolumn{2}{c}{$\mathbf{1 8 8 2}$} & \multicolumn{2}{c}{$\mathbf{1 9 4 1}$} & \multicolumn{2}{c}{$\mathbf{2 0 1 9}$} \\
\cline { 2 - 13 } & ha & $\mathbf{\%}$ & ha & $\mathbf{\%}$ & ha & $\mathbf{\%}$ & ha & $\mathbf{\%}$ & ha & \% \\
\hline Forest & 504.9 & 28.5 & 535.5 & 30.2 & 481.1 & 27.2 & 546.5 & 30.8 & 736.0 & 41.5 \\
\hline Woodland and shrubs & $\mathrm{x}$ & $\mathrm{x}$ & 3.9 & 0.2 & 104.5 & 5.9 & 224.0 & 12.6 & 165.2 & 9.3 \\
\hline Permanent grasslands & 158.1 & 8.9 & 364.2 & 20.6 & 157.6 & 8.9 & 141.3 & 8.0 & 150.2 & 8.5 \\
\hline Arable land & 1004.9 & 56.7 & 718.9 & 40.6 & 764.3 & 43.1 & 667.6 & 37.7 & 513.8 & 29.0 \\
\hline Gardens & 11.6 & 0.7 & 15.2 & 0.9 & 17.9 & 1.0 & 7.2 & 0.4 & 78.7 & 4.4 \\
\hline Vineyards & 69.4 & 3.9 & 106.9 & 6.0 & 114.4 & 6.5 & $\mathrm{x}$ & $\mathrm{x}$ & 1.9 & 0.1 \\
\hline Orchards and vineyard huts & $\mathrm{x}$ & $\mathrm{x}$ & 5.4 & 0.3 & 10.4 & 0.6 & 15.2 & 0.9 & 4.3 & 0.2 \\
\hline Water bodies & $\mathrm{x}$ & $\mathrm{x}$ & $\mathrm{x}$ & $\mathrm{x}$ & $\mathrm{x}$ & $\mathrm{x}$ & $\mathrm{x}$ & $\mathrm{x}$ & 2.4 & 0.1 \\
\hline Marshes & $\mathrm{x}$ & $\mathrm{x}$ & $\mathrm{x}$ & $\mathrm{x}$ & 92.9 & 5.2 & 97.7 & 5.5 & $\mathrm{x}$ & $\mathrm{x}$ \\
\hline Built-up area & 22.6 & 1.3 & 21.5 & 1.2 & 27.8 & 1.6 & 70.7 & 4.0 & 100.7 & 5.7 \\
\hline Cemetery & $\mathrm{x}$ & $\mathrm{x}$ & $\mathrm{x}$ & $\mathrm{x}$ & 0.6 & $\mathrm{x}$ & 1.3 & 0.1 & 0.9 & 0.1 \\
\hline Agro-industrial area & $\mathrm{x}$ & $\mathrm{x}$ & $\mathrm{x}$ & $\mathrm{x}$ & $\mathrm{x}$ & $\mathrm{x}$ & $\mathrm{x}$ & $\mathrm{x}$ & 17.4 & 1.0 \\
\hline$\sum$ & 1771.5 & 100.0 & 1771.5 & 100.0 & 1771.5 & 100.0 & 1771.5 & 100.0 & 1771.5 & 100.0 \\
\hline
\end{tabular}

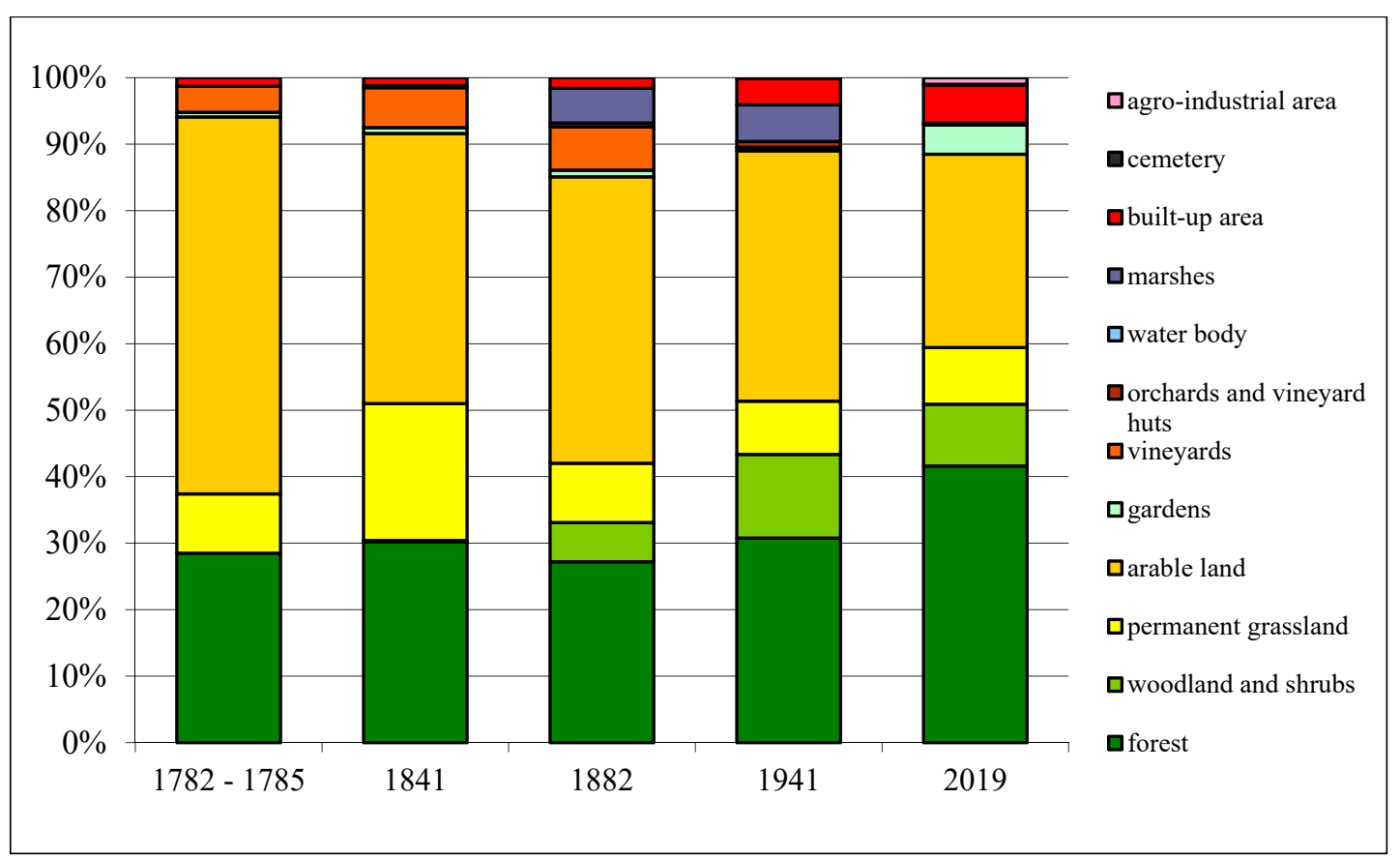

Figure 9. Visualization of the development of land use classes (LUC) of the studied area in the years 1782/1785-2019

\subsection{Analysis of Changes in the Historical Land-Use of the Studied Rural Historical Landscape in Terms of Its Stability}

The research results point to the importance of natural driving forces [95], which played an essential role in the process of anthropogenic exploitation of the local landscape during the observed periods. The agrarian potential of the studied area is reflected in the relatively stable LUC areas with a high rate of anthropogenic use (arable land, permanent crops), which limited the originality and ecological stability of the local landscape.

The dynamics of the forest area during approximately 237 years (1782-1785 to 2019) reflect the synergistic effect of sustainable management on the slopes of the Piliš Mts. Due to the mountain slopes' inclination, people usually used specific areas extensively and left them forested, in addition to the 
foothills (with temporal grasslands and arable land). Such development corresponds to the so-called "Forest Transition Theory" [96] (pp. 26-29). Slow and permanent (except in 1882) growth of forest area affected not only previously deforested mountain slopes, but also areas of agricultural land with different intensity of use (grasslands, arable land, and others), and this process was accompanied by the introduction of non-native species (pine, black locust).

The thermophilic oak forest covered about $28.5 \%$ (504.9 ha) of the studied area in 1782-1785 (Figure 8). Common pine could have also occurred in some places, on the edges of forest stands, or overgrown areas after extensive logging. The area of forests has changed only minimally (by two percentage points) since that period. Oak forest area has risen to 736 ha $(41.5 \%)$ in 2019 (Figure 8) since the second half of the 20th century, which represents an increase of almost $70 \%$ compared to the first period (Table 3, Figure 9).

There are two aspects of increasing the area of forest in the study area. The first reflects the effect of environmental risk on the intensive use of easily erodible soils on slopes with a greater inclination. Specific localities were gradually afforested, the trend of reforestation has been characteristic since the second half of the 19th century, especially for the mountain and foothill areas of the former Austria-Hungary, respectively the selected successor states in Central Europe [97-100]. Examples from the Slovak exclaves in Hungary-Békešská Čaba (hung. Békéscsaba) [9], Šára (hung. Sári) [6] and [101] suggest that the afforestation of areas in the lowlands has been replaced by systematic planting of non-forest woody vegetation or free spreading black locust, poplar, and other woody plants. Areas of permanent grasslands (PG) and non-forest woody vegetation (NDV) were also created here. The second aspect relates to the change in land-use priorities after 1989.

Grazing of horned cattle on the undergrowth of grassy oak forests supported the transformation of selected localities into pasture forests, e.g., Pánská hora hill [89] (p. 66). Areas of former pasture forests have changed their LUC to forests after the natural succession.

The analyzed LUC mitigates the relatively high values of the coefficient of anthropogenic influence (Cai) and the coefficient of cultural landscape originality (Cclo) of the studied area. The coefficient Kao starts from zero, while the upper limit does not exist. A value of 1 is reached when the area of both areal types is in equilibrium. Values higher than one means that areas with a high intensity of anthropogenic use predominate $-\mathrm{V}$ (arable land, settlements, built-up areas, permanent crops). In case of the predominance of less intensive areas- $\mathrm{N}$ (forest, permanent grassland, water area, alternatively also woodland and shrubs, wetland), the value of the coefficient approaches 0 [102] (p. 17). The Cclo coefficient expresses the ratio of relatively positive (forest, permanent grasslands) and relatively negative elements of the landscape (arable land). If this ratio exceeds 1, the landscape is stable and vice versa-the landscape becomes unstable when the value approaches 0 [103] (p. 148). The expansion of forest areas since the middle of the 20th century has also had a positive impact on the course of both coefficients, which indicates a gradual improvement in the ecological stability of the landscape (Table 4).

Table 4. Development of coefficient of anthropogenic influence (Cai) and coefficient of cultural landscape originality (Cclo) from 1782-1785 to 2009.

\begin{tabular}{cccccc}
\hline Coeficient & $\mathbf{1 7 8 2 - 1 7 8 5}$ & $\mathbf{1 8 4 1}$ & $\mathbf{1 8 8 2}$ & $\mathbf{1 9 4 1}$ & $\mathbf{2 0 1 9}$ \\
\hline Cai $=\mathrm{V} / \mathrm{N}$ & 1.7 & 0.9 & 1.1 & 0.8 & 0.7 \\
\hline Cclo $=$ forest + grasslands $/$ arable land & 0.7 & 1.3 & 0.8 & 1.0 & 1.7 \\
\hline
\end{tabular}

Woodland and shrubs. The given LUC was represented by opened or connected stands of woody plants (e.g., black locust, pine, willow, poplar, mulberry) and shrubs (hawthorn and similar). People have often cultivated these communities by pruning branches and shoots (pollarding) in the vicinity of vineyards, orchards, or fields. Woodland and shrubs have appeared in the landscape structure of the area since 1841 ( $3.9 \mathrm{ha}$ ). Copses were present near vineyards on the southwestern edge of the area (Figure 8). The area was 104.5 ha (approx. 6\%) in the next period (1882). The area of the 
woodland and shrubs on the forest edges, potholes, tree lines, and smaller, unconnected stands reached up to 224 ha, i.e., 12.6\% of the total area in 1941 (Figures 8 and 9). According to Table 3, this LUC area decreased by about 3\% (165.2 ha) by 2019.

The existence of woodland and shrubs areas in the studied area's landscape structure has a positive impact on mitigating the negative impact of plowing on the local landscape and its ecological stability. The extent of this LUC has been growing since the last quarter of the 19th century, shown by Cai and Cclo coefficients in Table 4.

The location and area of intensive LUCs (arable land, permanent cultures, settlements) in the years 1782-1785 to 2019 were the result of the interaction of historical factors and social driving forces. The Slovak population began to cultivate the wasteland on the edge of the Dorog Basin bordered by the slopes of Piliš Mts. between 1701 and 1709.

Analogous contexts of natural and social driving forces of land-use were also found in the Slovak exclaves of Cápar (hung. Szápár), Čerňa (hung. Bakonycsernye), and Jášd' (hung. Jásd) in Hungary [80] or Borumlak (rom. Borumlaca) and Varzal' (rom. Vărzari) in Romania [14].

Analyses confirmed that in 1782-1785 the meadows and pastures (permanent grasslands) spread mainly on the floodplain of the Čív Brook (site Velká and Malá pažíc, Dolná pažíc, Dlhé luki). Their area reached less than 158 ha (approximately 9\%). By 1841, this LUC area more than doubled to 364 ha, $20.6 \%$. This significant increase is probably related to the grassing of eroded fields, which arose in places with sandy soils (e.g., Homoki) or in the wet valley bottoms (Figure 8). The emergence of new pastures was not directly related to the development of animal production in the village. The area of permanent grasslands in the studied area has been without significant changes from the eighties of the 19th century until the present (2019) (Table 3, Figure 9). A relatively small number of cattle grazed the pastures; in 1911, it was only 13 pcs/100 inhabitants [104] (p. 153). Some areas of meadows and pastures (or vineyards) were built up (Homoki) in the second half of the 20th century. This decrease was induced by the transformation of arable land into permanent grasslands at the Tatarské salaše hill and elsewhere (Figure 8). Some parts of arable land (e.g., Na vršku hill and sites Pustovňík, Ot Santova) are temporarily used as grasslands, which is potentially related to the European Union's agricultural policy.

The area of grasslands remained relatively stable during the observed periods. Development of Cai and Cclo coefficients in Table 4 shows that meadows and pastures, along with other, less intensive LUCs (forest, woodland and shrubs), were (and are) important in improving the ecological stability of the landscape.

The arable land occupied almost 57\% of the area surveyed in the first period (1782-1785). In addition to localities with a high groundwater level (e.g., the floodplain of the Čív Brook) and the afforested slopes of the Piliš Mts. with a steeper inclination, the fields managed by the three-field system spread practically over the entire area (Figure 8). Their extent was approximately 1005 ha. By 1841, the area of arable land had decreased by $16 \%$ (718.9 ha). This phenomenon is primarily related to the grassing of eroded fields on loess and windy sands. According to map 2, the selected areas of arable land on the warm substrates of the basin uplands were transformed into vineyards (e.g., Homoki, Holé vrški, Od Lamváru sites). The increase in the area of fields in 1882 (764.3 ha) did not have a more permanent character, because there was a gradual reduction in the extent of arable land in the studied area in the next time horizons (1941 and 2019), which was not significantly affected by collectivization (Table 3, Figure 9). The development of plant production was limited by natural driving forces, and natural conditions, especially light soils, slope inclination, and wetting of selected localities.

For this reason, Slovak farmers from Čív, there was a lease (renting) of fields in the nearby village of Jászfalu, and Pilisjászfalu which inhabited the Hungarian [93] (p. 77). A significant reduction of arable land areas in or near urban areas began in the 1970s. The reduction was also related to the expansion of the settlement itself, and the spatial expansion of agricultural and industrial area on the 
southwestern edge of the territory (Figure 8). Following Hungary's accession to the E.U., the fields in the east and south-east of the study area were converted to grasslands.

The large extent of the LUC in question negatively affects the local landscape's originality and ecological stability. The Cai and Cclo coefficients show a considerable anthropogenic load, especially during the first period (1782-1785). The area of arable land decreased in the following periods, which also had a positive effect on the coefficients (Table 4).

The home gardens were created together with the development of the village's urban area (Figure 8). In 1782-1785, they occupied 11.6 ha. The area of gardens increased to 15.2 ha by 1841 . There was an increase in this LUC (17.9 ha) in the third period (1882). The significant decrease in the area of home gardens in 1941 does not correspond to reality but is related to the generalization of the underlying map's content. The largest area of gardens was in 2019 (78.7 ha), representing more than 6.5 times increase compared to the first time horizon (Table 3, Figure 9).

The vineyards in the Starí vinohrad and Vršek hills occupied an area of 69.4 ha (Figure 8) in 1782-1785. This relatively large area proves the developed viticulture in Čív. During the 19th century, there was an expansion of the existing and creation of new vineyards on the sunny slopes of the basin hills, protected from the wind by the forest stands (sites Homoki, Od Verešvára, and others). The reason was the quality of the wine, which motivated the local population to transform the sloping, less productive fields on light soils such as regosol or brown soil. In 1841, the area of the analyzed LUC was 106.9 ha (6.0\%). In 1882, vineyards with an area of 114.4 ha covered about $6.5 \%$ of the area studied. At the beginning of the 20th century, vineyards were also located at the Tatarske salaše hill [91] (p. 18). The given LUC is absent on the map from 1941 (Figure 8); the reason is the scale, and the generalized content of the cartographic base. However, the field research confirmed that viticulture continued to develop in the village also during this period.

In 2019 , the vineyards occupied only 1.9 ha, i.e., $0.1 \%$ of the studied area (Figure 8 ). Unused, abandoned vineyards were absorbed by the village urban area's development, or they were transformed into social fallows with grasslands and other LUCs. The development of vineyard areas is shown in Table 3 and Figure 9.

Orchards with vineyard huts and cellars were not mapped in the studied area until 1841 (Figure 8). Their extent almost doubled to 18.4 ha by 1882 from the original 5.4 ha (Figure 8). The increase in their area is also characteristic for 1941 when they covered an area of 15.2 ha (Figure 8). However, the acreage of orchards with viticultural architecture decreased to 4.3 ha in the last time horizon (2019) (Figure 8 ). The reason is the transformation of selected areas into extensive grasslands and residential development (Figures 8 and 9, Table 3).

The areas of permanent crops influenced the degree of anthropogenic influence of the local landscape together with the selected LUCs, as reflected in the development of the Cai coefficient in Table 4.

The LUC vineyards and orchards (including vineyard huts and cellars) represent characteristic elements of the studied area's landscape structure. Specific areas were used as grasslands and building plots after 1989 (Homoki site). Vineyards and orchards with vineyard huts at Starí vinohrad hill also lost their significance at the end of the 20th century. However, the archetype of the vineyard landscape with a landscape-creating and recreational function has been preserved.

The wetland on the floodplain of the Čív Brook was mapped in the area only in 1882 and 1941 (Figure 8). The data from Table 3 indicate a stable area of this LUC, which was around 95 ha. Interestingly, the wetland was not found at these sites on cartographic data from other periods, which, however, does not correspond to reality-e.g., wet grasslands (Figure 8) spread here in the years 1782-1785 and 1841. It was possible to use some areas of the former wetland as fields and gardens, or areas of non-forest woody vegetation formed by hydrophilic woody plants (willow, poplar, and others) after the land consolidation in the second half of the 20th century. This character of land-use was maintained until 2019 (Figure 8). 
The wetland area (together with forests, grasslands, and other extensive LUCs) mitigated the intensity of the anthropogenic influence during the two periods (1882 and 1941), which is confirmed by the values of Cai in Table 3.

The areal extent of settlements increased during the specific periods following the growth of Čiv's population (Figure 10).

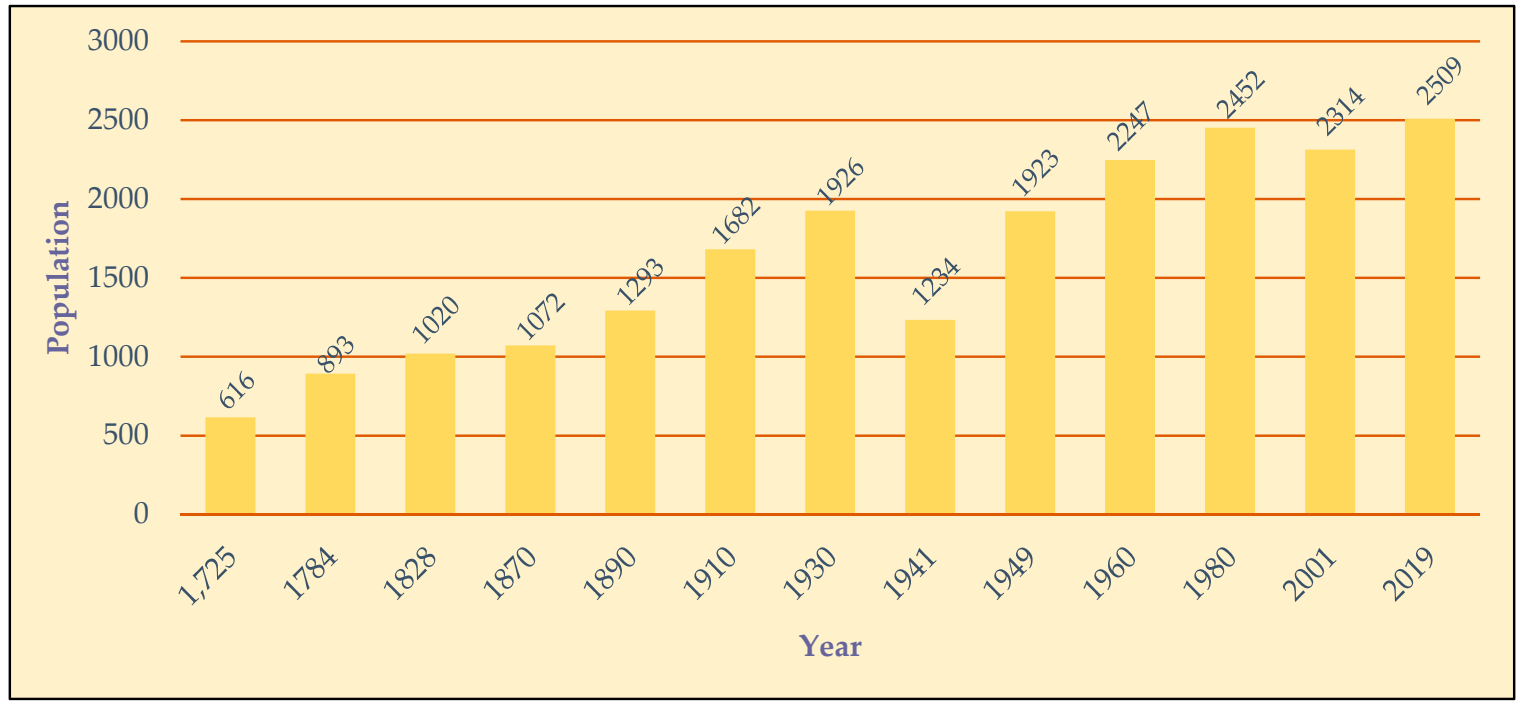

Figure 10. Development of Čív population form the 18th to the 21st century E. Fügedi [93] (p. 77), Piliscsév népessége (1870-2019).

In 1782-1785, the settlement spread over an area of 22.6 ha. The village had the character of a compact settlement with an irregular and seemingly chaotic arrangement of streets with houses that marked dry or drier locations in the basin (Figure 8). The LUC area and spatial disposition did not change significantly even during the two following periods $(1841,1882)$, which is confirmed by the data in Table 3, Figure 8.

The economic effect of job opportunities in the coal mines of town Dorog (and additional jobs in quarries and lime production) and the alternating system of arable land management manifested itself by an increase in natural growth, which increased the population of the village. Immigration from the surrounding settlements also played a role. These factors caused the built-up area extent to increase more than 2.5 times to 70.7 ha by 1941. According to Figure 8, the construction of new houses has affected fields, grasslands, and vineyards near the southern edge of the urban area. In 2019, the area of the monitored LUC exceeded 100 ha. Mainly the sloping locations with vineyards (Homoki site), fields, and grasslands (Dlhé, Dlhé lúki sites) were used as development areas for a set of new buildings in Čív or Piliscsév (Hungarian name of the village since 1954), or the existing built-up areas in the village became more concentrated.

The oldest cemetery in the village is located at Vršek hill near the Calvary. An elevated position was the motive for the cemetery location, together with a suitable substrate (dry loess) and the proximity of human settlements with a church.

The cemetery, with an area of $0.6 \mathrm{ha}$, has appeared in the landscape structure of the studied area since 1882. It was located in the southern part of the built-up area, today's kindergarten. In 1941 it was mapped on an area of 1.3 hectares. The new cemetery at Vinohrady (in Homoki site) had an area of about 1 ha in 2019. A military cemetery for members of the Red Army, victims of World War II, is situated at the kindergarten, at the crossroads of Béke Street and Vörösvári Street.

The areal extent of the agro-industrial site on the southwestern edge of the studied area reached 17.4 ha in 2019 (Table 3). Kilns for lime burning stood initially in these places [89] (p. 68), which is also confirmed by the map marker on the cartographic base from 1941. 
The areal extent of settlements during particular periods (in 2019 also the area of the agro-industrial site) influenced the values of the Cai coefficient (Table 4). The relatively small areal extent of positive LUCs (forest, grasslands, woodland, and shrubs) could not significantly compensate for the intense anthropogenic pressure on the landscape of the studied area. The improvement of the situation in 2019 is mainly related to the decline in crop production on less efficient areas of agricultural land.

\subsection{Sustainable Ecotourism of Rural Historical (Čív) Landscape}

At present, the village is not a tourist destination, but research results indicate that the cultural landscape around Slovak exclave Čív (historic buildings and the Dorog basin itself) has the potential for development of ecotourism (individual tourism, or tourism for small groups, such as families with children). In terms of the development of recreational activities, the historical landscape has the potential for cultural tourism (folk traditions, municipal museum), hiking, cycling, and agrotourism.

Based on the research of the study area, we can also determine the position of the cultural landscape of the Dorog basin as the primary source for the development of rural cultural tourism, in which ecotourism finds its most significant application.

The cultural landscape of Slovak exclave Čív provides the potential for the development of cultural rural tourism, which can take the form of ethic tourism, religious tourism, adventure tourism, gastronomic tourism, dark tourism, tourism of living history due to its specific landscape elements, and inhabitants (Figure 11).

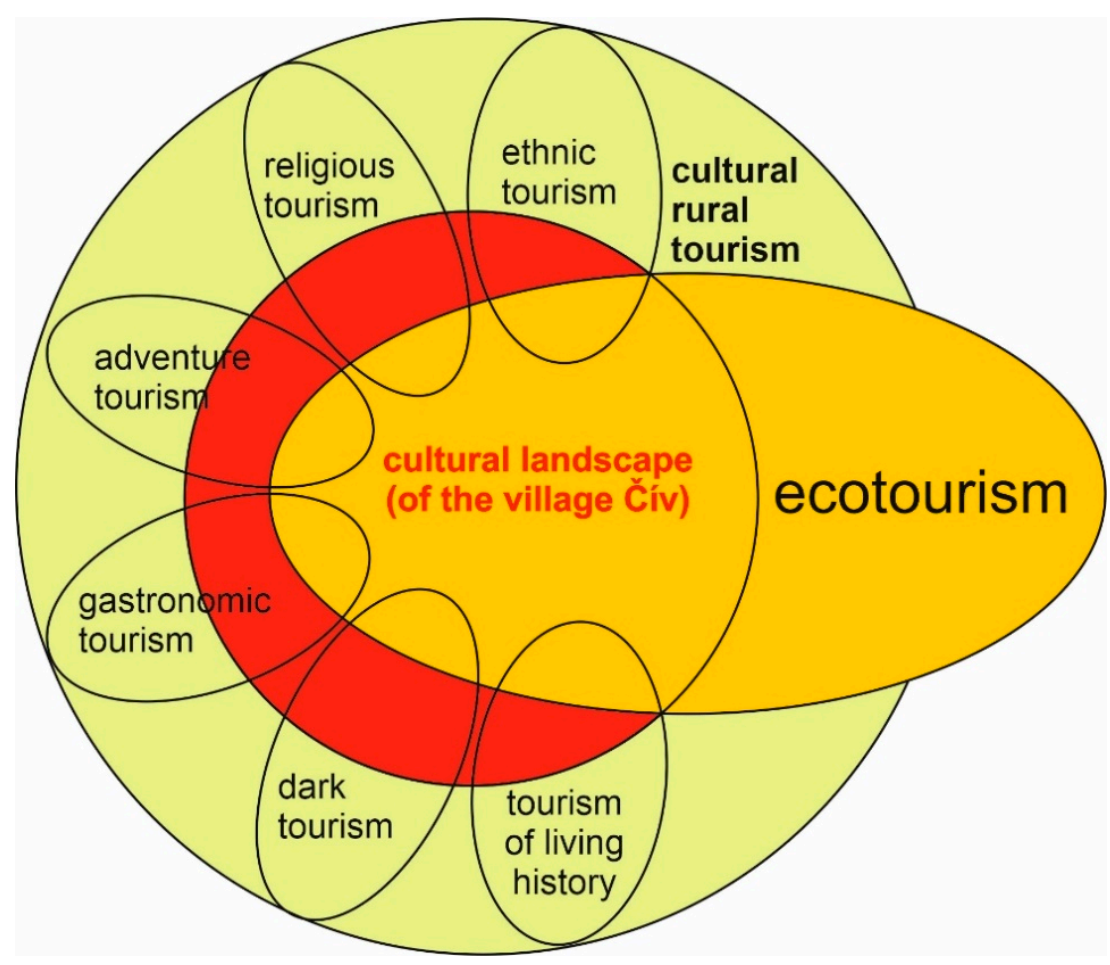

Figure 11. The position of cultural landscape of the village of Čív (in the Dorog Basin) as a primary source of development of individual types of tourism with an emphasis on ecotourism. Source: authors' research

In order for modern ecotourism to be sustainable in a long-term stable cultural rural landscape, it must be formed by closed-cyclical components (criteria) in interaction with the local community, i.e., in the case of our research, by a rural settlement-the municipality of Č́v. It must also be environmentally friendly to the surrounding landscape, and it must be in accordance with the protection and preservation of natural and cultural components of the landscape (Figure 12). In order for ecotourism to be sustainable in a historic rural landscape, we must consider them both as 
interconnected vessels. If the (sustainable) historical rural landscape is stabilized, ecotourism will also be sustainable, and vice versa, if the historic landscape is unsustainable, ecotourism will also be unsustainable.

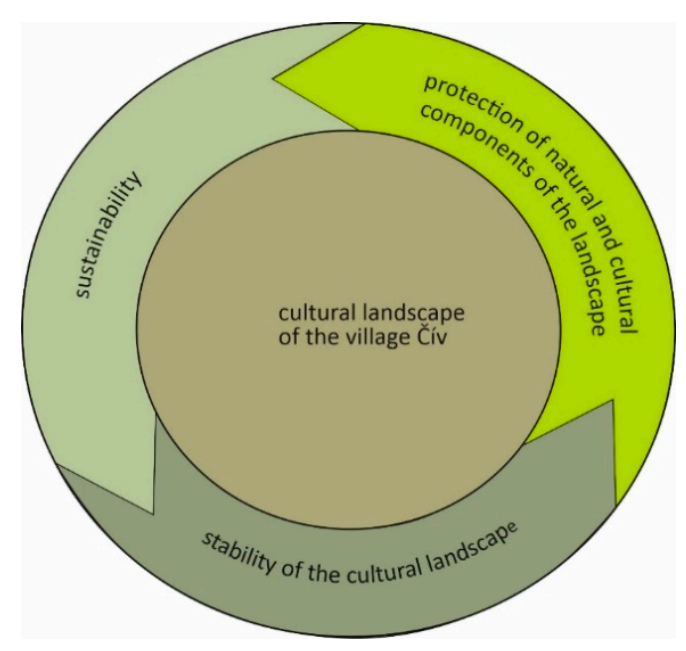

Figure 12. Sustainable ecotourism in the cultural landscape is formed by cyclical components (criteria) in interaction with the local community (rural settlement-municipality Čív). (Modified and supplemented based on the authors' research according to Trifumov, Soim [44]).

In order for the country to maintain its long-term potential for sustainable tourism, it is necessary to manage its current state in terms of proposals that we have compiled on the basis of research results and present them at the end of the paper. The proposals emphasize the four pillars on which sustainable ecotourism (ecological, economic, social, and cultural) is built.

\section{Discussion}

The historical rural landscape as a source for the development of sustainable ecotourism in the Carpathian Mountains of Central Europe represents a substantial potential for this European region, which has not yet been fully exploited.

Wilderness (natural landscape), which forms the essential space for ecotourism development, no longer exists in Central Europe (Carpathian region). It disappeared due to the influence of human society and anthropogenic transformations, which have acquired an intense character in this area since the Middle Ages. The last written reports about the existence of the primeval forests in the Carpathian Basin are from the turn of the 12th and 13th centuries. It was a relatively sparsely populated region at the beginning of the 13th century, as evidenced by the report preserved in the chronicle called Gesta Hungarorum, but better known as the Anonymous Chronicle, written by an anonymous notary who probably served under King Belo III. (1173-1196). Its content is also a contemporary description of the landscape as it existed in this period in the Carpathian Mountains of Central Europe. The chronicle mentions an extensive royal forest, or a primeval forest [105]. Other documents also confirm the presence of large forested areas in this geographical area at the turn of the 12th and 13th centuries, in which settlements are gradually beginning to densify [106]. During this period, we can look for the emergence of a cultural landscape in the Carpathian Mountains, which currently occupies almost the entire territory. The above-mentioned national parks are also an example.

It is the stable cultural landscape, as a "natural" heritage, that is becoming an increasingly sought-after environment for tourism, or rather ecotourism, in this geographical area. Our research confirms the potential and suitability of a cultural landscape for ecotourism of the Slovak exclave Č́v. By comparing selected indicators (pros and cons) influencing the development of ecotourism in a cultural landscape resulting from our research and based on the evaluation of literary sources related to the wilderness (as the primary space for the development of ecotourism), we found that a cultural 
landscape is more suitable (more attractive) for the development of ecotourism than wilderness in many cases (Table 5). We can point out the characteristics of the landscape, such as its vastness, naturalness, and natural diversity, which significantly dominate in the wilderness. However, on the contrary, the cultural landscape has the advantage for today's ecotourist that it is relatively more comfortable and much faster to access. The remoteness of the wilderness can have a significant negative impact on time and transport, representing an increased financial cost.

Table 5. Basic characteristics of the environment (wilderness-cultural landscape) suitable for the development of ecotourism from the point of view of modern (contemporary) ecotourist (basic specifics resulting from the research of authors in the cultural landscape of the Dorog Basin). The green color indicates better conditions for ecotourism in one environment compared to another.

\begin{tabular}{cc}
\hline \multicolumn{1}{c}{ Wilderness } & Cultural Landscape \\
\hline the vastness of the landscape & the vastness of the landscape \\
\hline natural landscape & natural landscape \\
\hline relatively short distance for the client & relatively short distance for the client \\
\hline natural diversity & natural diversity \\
\hline cultural diversity & cultural diversity \\
\hline the originality of local communities & the originality of local communities \\
\hline health risks & health risks \\
\hline ambulance availability & ambulance availability \\
\hline access to the Internet and social networks in terms of security & access to the Internet and social networks in terms of security \\
\hline elements of adrenaline tourism & elements of adrenaline tourism \\
\hline the uniqueness of the visual experience & the uniqueness of the visual experience \\
\hline hiking trails and local roads & hiking trails and local roads \\
\hline Touristic facilities & Touristic facilities \\
\hline The need for tourist guides & The need for tourist guides \\
\hline Physical fitness of ecotourists & General knowledge of potential ecotourists about the area \\
\hline Estimated financial costs & Physical fitness of ecotourists \\
\hline
\end{tabular}

Cultural diversity, whether of the landscape itself or the cultural (technical) monuments, is significantly more attractive for today's tourists than sterile monotonous (large) cities. The reduction of health risks and the relative availability of health care, which, on the other hand, can reduce the adrenaline attractiveness of this environment, are closely related to the advantages of the cultural landscape mentioned above. Almost complete coverage of areas with an Internet signal in Central Europe's cultural landscape enables fast, high-quality and cheap communication with "civilization". The cultural landscape also provides "comfort" for modern ecotourists with a relatively dense structure of roads, hiking trails, and other necessary infrastructure.

It is also debatable, which will require further research, whether the rural landscape with its communities is attractive enough for ecotourists compared to a natural community outside of civilization in a remote primeval forest-wilderness.

\section{Conclusions}

The development of selected and researched LUCs and the identified archetypes of the landscape reflects the specifics of the so-called land-use driving forces. The effective use of research results and their transfer into social practice can be realized through cultural and educational activities aimed at supporting the identity of the local population [107,108]. The Minority Slovak local government can saturate this role in cooperation with the municipality's management.

The research results also can address the issues and problems of harmonization and revitalization of the natural and socio-economic subsystems of the local landscape. The methodology used and the results obtained can be applied in basic research in the study of similar areas. Findings on changes in the local landscape, their aspects, and contexts can be used, e.g., to saturate social practice in the creation of integrated landscape management, which we present in the form of framework proposals. Their goal is to harmonize the development of anthropogenic activities while preserving the cultural and historical potential of the studied area and its sustainability through ecotourism. In order for 
the rural cultural landscape to maintain agreed stability with the possibility of sustainable use in ecotourism, it would be appropriate to put the following proposals resulting from the research results into practice:

Proposal no. 1: It is necessary to support the biodiversity (as one of the elements of ecotourism) in the basin by increasing the area of permanent grasslands through delimitation of the temporarily grassed arable land, revitalization of wetlands on the floodplain of Čív Brook, and non-forest woody vegetation, to preserve the local landscape's ecological stability.

Proposal no. 2: Ensuring the social and cultural diversity of the local landscape through the restoration and maintenance of the traditional way of life of the "original" Slovak inhabitants of the village. In terms of ecotourism development, it is primarily a matter of gaining an authentic experience of learning about the traditional tangible and intangible culture and local cuisine.

Proposal no. 3: Ensuring the active economic involvement of the local community in the development of ecotourism in the form of offering local services and products (especially the production of traditional souvenirs, preparation of local cuisine, preparation of traditional cultural and social events, and the provision of guide services).

These proposals can stabilize and preserve the heritage of the cultural landscape as the primary source for the development of ecotourism, which would lead to mutual interaction and sustainability not only of the cultural landscape and its tangible and intangible elements itself but also of ecotourism.

Author Contributions: Conceptualization, P.H., B.G. and P.C.; methodology, P.C., P.H. and B.G.; software, M.Ž.; validation, M.Ž., B.G. and P.H.; formal analysis, P.C., B.G. and P.H.; investigation, B.G. and P.H.; resources, P.C., P.H., B.G. and M.Ž.; data curation, P.C., and M.Ž.; writing—original draft preparation, P.C., P.H., B.G. and M.Ž.; writing-review and editing, P.H., B.G. and M.Ž.; visualization, P.C., P.H., B.G. and M.Z.; supervision, P.C., P.H.; project administration, B.G.; funding acquisition, P.C. All authors have read and agree to the published version of the manuscript.

Funding: This research and the APC was funded by SLOVAK RESEARCH AND DEVELOPMENT AGENCY, grant number APVV-18-0196 "Vedomosti Nitrianskej stolice M. Bela (interpretácia a aplikácia)", and grant number APVV-18-0185 “Transformácia využívania kultúrnej krajiny Slovenska a predikcia jej d'alšieho vývoja” and also by CULTURAL AND EDUCATIONAL GRANT AGENCY, grant number 005UCM/4-2019 "Prírodné pomery Nitrianskej stolice v 18. storočí pohl'adom M. Bela (vysokoškolská učebnica)".

Conflicts of Interest: The authors declare no conflict of interest. The funders had no role in the design of the study; in the collection, analyses, or interpretation of data; in the writing of the manuscript, or in the decision to publish the results.

\section{References}

1. Fescenko, A.; Nikodemus, O.; Brūmelis, G. Past and Contemporary Changes in Forest Cover and Forest Continuity in Relation to Solis (Suthern Latvia). Pol. J. Ecol. 2014, 62, 625-638. [CrossRef]

2. Olah, B.; Boltižiar, M.; Gallay, I. Transformation of the Slovak cultural landscape since the 18th century and its recent trends. J. Landsc. Ecol. 2009, 2, 41-55. [CrossRef]

3. Fialová, D.; Chromý, P.; Marada, M. Historicko geografická analýza změn funkčního využití břehů Vltavy (v období od přelomu 18. a 19. století do současnosti). Hist. Geogr. 2007, 34, 307-317.

4. Trpáková, I. Krajina ve Světle Starých Pramenů; Lesnická práce: Praha, Czech Republic, 2013; p. 248.

5. Wang, W.; Zhang, C.H.; Allen, J.; Li, W.; Boyer, M.; Segerson, K.; Silander, J. Analysis and prediction of land use changes related to invasive species and major driving forces in the State of Connecticut. Land 2016, 5, 25. [CrossRef]

6. Boltižiar, M.; Chrastina, P.; Trojan, J. Vývoj využívania kultúrnej krajiny slovenskej enklávy Šára v Mad'arsku (1696-2011). Geogr. Inf. 2016, 20, 24-37.

7. Chrastina, P. Krajina Vel'kého Bánhedeša a jej Premeny. In Acta Nitriensiae 10; Gadušová, Z., Ed.; FF UKF: Nitra, Slovakia, 2008; pp. 74-94.

8. Chrastina, P. Pivnica: Krajina—človek—kultúra slovenskej enklávy v srbskej Báčke. In Svedectvá Slovenského Dolnozemského Bytia: Aspekty zo Slovenskej Dolnozemskej Kultúrnej Histórie a Kultúrnej Antropológie; Ambruš, I.M., Ed.; Vyd. I. Krasko: Nadlak, Romania, 2012; pp. 187-201. 
9. Chrastina, P. Zmeny využívania krajiny Békešskej Čaby. In Kapitoly z Minulosti a Súčasnosti Slovákov v Békešskej Čabe; Kmet', M., Tušková, T., Uhrinová, A., Eds.; Magyarországi Szlovákok Kutatóintézete: Békešská Čaba, Hungary, 2018; pp. 378-401.

10. Chrastina, P.; Boltižiar, M. Butín: Krajina—človek—kultúra slovenskej enklávy v rumunskom Banáte. Studia Hist. Nitriensia 2008, 14, 165-193.

11. Chrastina, P.; Boltižiar, M. Senváclav: Krajina—človek—kultúra slovenskej enklávy vo Vyšegrádskych vrchoch. Studia Hist. Nitriensia 2010, 15, 53-86.

12. Chrastina, P.; Trojan, J.; Župčán, L.; Tuska, T.; Hlásznik, P.P. Land use ako nástroj revitalizácie krajiny na príklade slovenskej exklávy Tardoš (Mad'arsko). Geogr. Cassoviensis 2019, 13, 121-140.

13. Chrastina, P.; Trojan, J.; Valášek, P. Historický “land use” Tardoša. In Slovenské Inšpirácie z Tardoša. 35. Interdisciplinárny výskumný tábor Výskumného ústavu Slovákov v Mad’arsku; Tušková, T., Žiláková, M., Eds.; VÚSM: Békešská Čaba, Hungary, 2018; pp. 65-88.

14. Chrastina, P.; Křováková, K.; Brůna, V. Zmeny krajiny v rumunskom Bihore (na príklade slovenskej enklávy Borumlak a Varzal'). Hist. Geogr. 2007, 32, 371-398.

15. Drumm, A.; Moore, A. Ecotourism Development-A Manual for Conservation Planners and Managers Volume 1: An Introduction to Ecotourism Planning, 2nd ed.; The Nature Conservancy: Arlington, VA, USA, 2005; p. 96.

16. Ziffer, K. Ecotourism: The Uneasy Alliance; Conservation International: Washington, DC, USA, 1989; p. 36.

17. Brandon, K. Ecotourism and Conservation: A Review of Key Issues; The World Bank: Washington, DC, USA, 1996; p. 80.

18. Honey, M. Ecotourism and Sustainable Development. Who owns Paradise? Island Press: Washington, DC, USA, 1999; p. 405.

19. Weaver, D.B. Magnitude of Ecotourism in Costa Rica and Kenya. Ann. Tour. Res. 1999, 26, 792-816. [CrossRef]

20. Weaver, D.B. Ecotourism; John Wiley \& Sons Inc: New York, NY, USA, 2008; p. 360.

21. Kurek, W. Turystyka; Wydawnictwo Naukowe PWN: Warszawa, Poland, 2008; p. 540.

22. Rahman, A. Application of GIS in Ecotourısm Development: A Case Study in Sundarbans, Bangladesh. Master's Thesis, Mid-Sweden University Master of Arts, Human Geography Focusing on Tourism, Sundsvall, Sweden, 2010; p. 79.

23. The International Ecotourism Society. Available online: https://ecotourism.org/what-is-ecotourism (accessed on 10 May 2020).

24. Global Ecotourism Network. Available online: https://www.globalecotourismnetwork.org (accessed on 10 May 2020).

25. Cambridge Dictionary. Available online: https://dictionary.cambridge.org/ (accessed on 10 May 2020).

26. Sharpley, R. Ecotourism: A Consumption Perspective. J. Ecotour 2006, 5, 7-22. [CrossRef]

27. Blamey, R.K. Principles of Ecotourism, the Encyclopedia of Ecotourism; CABI Publishing: New York, NY, USA, 2001; pp. 5-22.

28. Honey, M. Ecotourism and Sustainable Development: Who Own Paradise, 2nd ed.; Island Press: Washington, DC, USA, 2008.

29. Cheia, G. Ecotourism: Definition and concepts. J. Tour. 2013, 15, 56-60.

30. Fennell, D. A content analysis of ecotourism definitions. Curr. Issues Tour. 2001, 4, 403-421. [CrossRef]

31. Barkauskiene, K.; Snieska, V. Ecotourism as an Integral Part of Sustainable Tourism Development. Econ. Manag. 2013, 18, 449-456. [CrossRef]

32. Tsaur, S.; Lin, Y.; Lin, J. Evaluating Ecotourism Sustainability from the Integrated Perspective of Resource, Community and Tourism. Tour. Manag. 2006, 27, 640-653. [CrossRef]

33. Wall, G. Is ecotourism sustainable? Environ. Manag. 1997, 21, 483-491. [CrossRef]

34. Kim, M.; Xie, Y.; Cirella, G.T. Sustainable Transformative Economy: Community-Based Ecotourism. Sustainability 2019, 11, 4977. [CrossRef]

35. Donohoe, H.M. Defining culturally sensitive ecotourism: A Delphi consensus. Curr. Issues Tour. 2011, 14, 27-45. [CrossRef]

36. Luchman, H. Cultural Landscape Preservation and Ecotourism Development in Blambangan Biosphere Reserve, East Java. In Landscape Ecology for Sustainable Society; Hong, S.K., Nakagoshi, N., Eds.; Springer: Cham, Switzerland, 2018; pp. 341-358. 
37. Luchman, H.; Kim, J.; Hong, S. Cultural Landscape and Ecotourism in Bali Island, Indonesia. J. Ecol. Field Biol. 2009, 32, 1-8.

38. Poulot, D. Identity as Self-Discovery: The Ecomuseum in France. In Museum Culture: Histories, Discourses, Spectacles; Sherman, D., Rogoff, I., Eds.; Routledge: London, UK, 1994; pp. 66-84.

39. Schlichtherle, H. 'Der archäologische Moorlehrpfad im Südlichen Federseeried', in Urgeschichte Erleben Fährer zum Federseemuseum mit Archäologischem Freigelände und Moorlehrpfad; Verlagsbäro Wais \& Partner: Stuttgart, Germany, 2008; pp. 47-71.

40. Schlichtherle, H.; Strobel, M. Archaeology and Protection of Nature in the Federsee Bog; Landesdenkmalamt Baden-Württemberg: Stuttgart, Germany, 1999.

41. Russell, A. Sustaining Reflections on the Saimaa Lakes. Muut. Matk. 2001, 2, 60-63.

42. Wallace, G. Getting a Buzz from Winter Tourism on the Saimaa Lakes. Muut. Matk. 2002, 2, 68-71.

43. Kranjčević, J.; Šaban, S. Tourism in the cultural landscape. An attempt to create new value in the example of the Medvednica nature park, Croatia. In Tourism-Current and Future Challenges for Urban Development; Institut za turizam: Zagreb, Croatia, 2009; p. 13.

44. Trofimov, V.; Soimu, O. Ecotourism concept in the light of cultural diversity and regional development. Agric. Econ. Rural Dev. 2011, 8, 117-125.

45. Dzhandzhugazova, E.A.; Ilina, E.L.; Latkin, A.N.; Davydovich, A.R.; Valedinskaya, E.N. Ecotourism Programs in the Context of the Perception of Natural and Cultural Landscapes (on the Example of the Kizhi Museum Reserve). Ekoloji 2018, 27, 377-382.

46. Campbell, L. Ecotourism in rural developing communities. Ann. Tour. Res. 1999, 26, 534-553. [CrossRef]

47. Frochot, I. A benefit segmentation of tourists in rural areas: A Scottish perspective. Tour. Manag. 2005, 26, 335-346. [CrossRef]

48. Kiper, T.; Özdemir, G.; Sağlam, C. Enviromental, socio-cultural and economical effects of ecotourism perceived by the local people in the northwestern Turkey: Kiyiköy case. Sci. Res. Essays 2011, 6, 4009-4020.

49. Okan, T.; Köse, N.; Arifoğlu, E.; Köse, C. Assessing Ecotourism Potential of Traditional Wooden Architecture in Rural Areas: The Case of Papart Valley. Sustainability 2016, 8, 974. [CrossRef]

50. Bunruamkaew, K.; Murayama, Y. Land Use and Natural Resources Planning for Sustainable Ecotourism Using GIS in Surat Thani, Thailand. Sustainability 2012, 4, 412-429. [CrossRef]

51. Clifton, j.; Benson, A. Planning for Sustainable Ecotourism: The Case for Research Ecotourism in Developing Country Destinations. J. Sustain. Tour. 2006, 14, 238-254. [CrossRef]

52. Semple, W. Traditional architecture in Tibet: Linking issues of environmental and cultural sustainability. Mt. Res. Dev. 2005, 25, 15-19. [CrossRef]

53. Angelica, M.; Zambrano, A.; Broadbent, E.N.; Durham, W.H. Social and environmental effects of ecotourism in the Osa Peninsula of Costa Rica: The Lapa Rios case. J. Ecotourism 2010, 9, 62-83.

54. Pénzes, E. Országos ökoturizmus Fejlesztési Stratégia; Pannon Egyetem Turizmus Tanszék: Budapest, Hungary, 2008; p. 170.

55. Michalkó, G. Turizmológia: Elméleti alapok; Akadémiai Kiadó: Budapest, Hungary, 2012; 266p.

56. Matlovičová, K.; Klamár, R.; Mika, M. Turistika a Jej Formy; Fakulta humanitných a prírodných vied PU v Prešove: Prešov, Slovakia, 2015; p. 549.

57. Gregorová, B. The issue of pilgrimage tourism from the point of view of geography. Acta Geoturistica 2019, 10, 1-9.

58. Ryglová, K. Cestovní Ruch; KEY Publisching s.r.o.: Ostrava, Česká Republika, 2009; p. 187.

59. Zaręba, Dominika 2010: Ekoturystyka; Wydawnictwo Naukowe PWN: Warszawa, Poland, 2010; p. 180.

60. Kolejka, J. Czech experience with land use and land cover change research. In Land Use/Land Cover Changes in the Period of Globalization: Proceedings of the IGU-LUCC International Conference; Bičík, I., Chromý, P., Jančák, V., Janů, H., Eds.; Charles University: Prague, Czech Republic, 2002; pp. 144-152.

61. Gobin, A.; Campling, P.; Feyen, J. Logistic modelling to derive agricultural land use determinants: Case study from southeastern Nigeria. Agric. Ecosyst. Environ. 2002, 89, 213-228. [CrossRef]

62. Kuplich, T.M.; Freitas, C.C.; Soares, J.V. The study of ERS-1 SAR and Landsat TM synergism for land use classification. Int. J. Remote Sens. 2000, 21, 2101-2111. [CrossRef]

63. Bezák, P.; Izakovičová, Z.; Miklós, L. Reprezentatívne Typy Krajiny Slovenska; Ústav krajinnej Ekologié Slovenskej akadémie Vied: Bratislava, Slovakia, 2010. 
64. Köhler, R.; Olschofsky, K.; Gerard, F. Land Cover Change in Europe from the 1950'ies to 2000; Institute for Worldforestry, University of Hamburg: Hamburg, Germany, 2004.

65. Frisnyák, S. Magyarország tájai. In Magyarország Földrajza; Frisnyák, S., Ed.; Tankönyvkiadó: Budapest, Hungary, 1988; pp. 145-150.

66. Süli-Zakar, I. Dunántúli-közephegység. Dunazug-hegyvidék. In Magyarország földrajza; Frisnyák, S., Ed.; Tankönyvkiadó: Budapest, Hungary, 1988; pp. 238-243.

67. Šomšák, L. Flóra a Fauna v Rastlinných Spoločenstvách Strednej Európy (Aplikovaná Biocenológia); PríF UK: Bratislava, Slovakia, 1998; p. 308.

68. Dražil, T. Teplomilné ponticko-panónske dubové lesy na spraši a piesku. In Katalóg biotopov Slovenska; Stanová, V., Valachovič, M., Eds.; Daphne: Bratislava, Slovakia, 2002; pp. 93-94.

69. Krištofičová, E. 1997 Prostriedky Hodnotenia Knižničných a Vedeckoinformačných Procesov; CVTI: Bratislava, Slovakia, 1997; p. 157.

70. Carrizo-Sainero, G. Toward a Concept of Bibliometrics. J. Span. Res. Inf. Sci. 2000, 1, 1-6.

71. Ondrišová, M. Bibliometria; STIMUL: Bratislava, Slovakia, 2011; p. 134.

72. Hartshorne, R. The Concept of Geography as a Science of Space, from Kant and Humboldt to Hettner. Ann. Assoc. Am. Geogr. 1958, 48, 97-108. [CrossRef]

73. Demek, J. Úvod do štúdia Teoretickej Geografie; SPN: Bratislava, Slovakia, 1987; p. 241.

74. Ivanička, K. Základy Teórie a Metodológie Socioekonomickej Geografie; SPN: Bratislava, Slovakia, 1983; p. 432.

75. Butlin, R.A.; Dodgshon, R.A. An Historical Geography of Europe; Claredon Press: Oxford, UK, 1998; p. 373.

76. Chrastina, P. Krajina ako jeden zo styčných fenoménov prírodných a spoločenských vied. Acta Hist. Nitriensia 2001, 4, 333-344.

77. Chrastina, P. Vývoj Využívania Krajiny Trenčlanskej Kotliny a jej Horskej Obruby; UKF: Nitra, Slovakia, 2009 ; p. 285.

78. Rábik, V.; Labanc, P.; Tibenský, M. Historická Geografia; Filozofická fakulta Trnavskej univerzity v Trnave: Trnava, Slovakias, 2013; p. 82.

79. Semotanová, E. Historická Geografie českých zemí; Historický ústav AV ČR: Praha, Czech Republic, 2002; p. 279.

80. Chrastina, P.; Boltižiar, M. Historicko-kultúrn Ogeografické črty obcí Čápar, Čerňa a Jášt'. In Kultúrne Tradície Slovákov v Oblasti Bakonského Lesa; Šusteková, I., Ed.; FF UKF: Nitra, Slovakia, 2008; pp. 7-33.

81. Mapire. Available online: https://mapire.eu/en/ (accessed on 15 May 2020).

82. Google Earth. Available online: https://earth.google.com/web/ (accessed on 1 May 2020).

83. Timár, G.; Lévai, P.; Molnár, G.; Varga, J. A második világháború német katonai térképeinek koordinátarendszere. Geodézia És Kartográfia 2004, 56, 25-35.

84. Timár, G.; Molnár, G.; Székely, B.; Biszak, S.; Varga, J.; Jankó, A. Digitized Maps of the Habsburg Empire-The Map Sheets of the Second Military Survey and Their Georeferenced Version; Arcanum: Budapest, Hungary, 2006; p. 59.

85. Timár, G.; Biszak, S. Digitizing and georeferencing of the historical cadastral maps (1856-60) of Hungary. In Proceedings of the 5th International Workshop on Digital Approaches in Cartographic Heritage, Vienna, Austria, 22-24 February 2010.

86. Blišt'an, P. Geographic information system for major mining area Dubník-opalmines. In Proceedings of the SGEM 2013: 13th International Multidisciplinary Scientific GeoConference: Informatics, Geoinformatics and Remote Sensing; STEF92 Technology Ltd.: Albena, Bulgaria, 2013; pp. 729-736.

87. Blišt'an, P. Some possibilities of using geographic information systems in analysis of the potential of destination Slovensky raj (Slovakia) in tourism. In Advances and trends in geodesy, cartography and Geoinformatics: Proceedings of the 10 International Scientific and Professional Conference on Geodesy, Cartography and Geoinformatics; CRC Press: Leiden, The Netherland, 2018; pp. 147-152.

88. Blišt’an, P.; Šoltésová, M.; Kršák, B.; Sidor, C.; Štrba, L'. Modelling of geological phenomena in GIS (Geographical information system). Metalurgija 2008, 47, 278.

89. Mihalovič, A. Zemepisné Mená Čívu (Jazykovedná štúdia); Tankönyvkiadó: Budapest, Hungary, 1987; 147p.

90. Osváth, A. Komárom és Esztergom KözigazgatáSilag Egyelöre Egyesitett Vármegyék Multja és Jelene; A Magyar Vármegyék és Városok Multja és Jelene: Budapest, Hungary, 1938; p. 936.

91. Reiszig, E. Esztergom vármegyei köszégei. In Esztergom Vármegye (Magyarország Vármegyéi és Városai); Borovszky, S., Ed.; Országos Monografia Társaság: Budapest, Hungary, 1908; pp. 6-39.

92. Csombor, E. Piliscsév története. In 300 rokov v Piliši: Štúdie z Minulosti a Prítomnosti Čívu. (300 év a Pilisben: Tanulmányok Piliscsév múltjából és Jelenéből; Divičanová, A., Ed.; Piliscsévi Szlovák Kisebbségi Önkormányzat: Čív-Piliscsév, Hungary, 2002; pp. 15-29. 
93. Fügedi, E. Príspevky k dejinám osídlenia niektorých slovenských obcí na území dnešného Mad'arska: Čív (Csév). In Atlas Slovenských nárečí v Mad'arsku: Atlas der Slowakischen Mundarten in Ungarn; Király, P., Ed.; VÚSM: Budapest, Hungary, 1993; p. 77.

94. Udvari, I. A Mária Terézia-Féle úrbérrendezés Szlovák nyelvü Dokumentumai: Slovenské Dokumenty Urbárskej Regulácie Márie Terézie. Adatok a Szlovák nép Gazdaság-és Társadalomtörténetéhez (Szepességi Ruszin Falvak Népélete Mária Terézia Korában); Bessenyei György Kiadó: Nyíregyháza, Hungary, 1991; p. 370.

95. Bičík, I.; Jeleček, L.; Kabrda, J.; Kupková, L.; Lipský, Z.; Mareš, P.; Šefrna, L.; Winklerová, J. Vývoj využití ploch v Česku; Edice Geographica: Praha, Czech Republic, 2010; p. 251.

96. Mather, A. The reversal of land-use trends: The beginning of the reforestation of Europe. In Land Use/Land Cover Changes in the Period of Globalization: Proceedings of the IGU-LUCC International Conference; Bičík, I., Chromý, P., Jančák, V., Janů, H., Eds.; Charles University: Prague, Czech Republic, 2002; pp. 23-30.

97. Lettner, C.H.; Wrbka, T. Historical development of the cultural landscape at the nothern border of the Eastern Alps: General trends and regional peculiarities. In Proceedings: Workshop on Landscape History; Balász, P., Konkoly-Gyuró, E., Eds.; University of West Hungary Press: Sopron, Hungary, 2011; pp. 109-121.

98. Skokanová, H. Long-term changes in the landscape structure in three border areas, of the Czech Republic. In Proceedings: Workshop on Landscape History; Balász, P., Konkoly-Gyuró, E., Eds.; University of West Hungary Press: Sopron, Hungary, 2011; pp. 152-160.

99. Krausmann, F.; Naberl, H.; Schulz, N.B.; Erb, K.; Darge, E.; Gaube, V. Land-use change and socioeconomic metabolism in Austria, Part I: Driving forces of land-use change: 1950-1995. Land Use Policy 2003, 20, 1-20. [CrossRef]

100. Hanuškin, J.; Lacika, J. Vybrané environmentálne súvislosti zmien historickej lazníckej krajiny (na príklade obce Hrušov okres Vel'ký Krtíš). Geogr. Časopis 2018, 70, 57-77.

101. Trojan, J.; Chrastina, P.; Boltižiar, M. Case study area Vel'ký Bánhedeš/Nagybánhegyes: Land use changes from the past to 2015. In Land Use/Cover Changes in Selected Regions in the World; International Geographical Union: Asahikawa, Japan, 2018; pp. 53-60.

102. Kupková, L. Data o krajině včera a dnes. 160 let v tváři české kulturní krajiny. GEOInfo 2001, 7, 16-19.

103. Žigrai, F. Forming of the Cultural Landscape of Liptov in the Past and Today. Acta Geogr. Univ. Comen. Econ.-Geogr. 1971, 10, 137-155.

104. Auerhan, J. Čechoslováci v Jugoslávii, v Rumunsku, v Mad'arsku a v Bulharsku; Melantrich: Praha, Czech Republic, 1921; p. 203.

105. Múcska, V. Kronika Anonymného Notára Král'a Bela: Gesta Hungarorum; Vydavatel'stvo Rak: Budmerice, Czech Republic, 2000; p. 159.

106. Musil, F. Gesta Hungarprum a historicko-zemepisný obraz Slovenska. Hist. Časopis 2004, 52, 433-450.

107. Králik, R.; Lenovský, L.; Pavlíková, M. A few comments on identity and culture of one ethnic minority in central Europe. Eur. J. Sci. Theol. 2018, 14, 63-76.

108. Lenovský, L. Identity as an Instrument for Interpreting the Socio-cultural Reality. Eur. J. Sci. Theol. 2015, 11, 171-184.

(C) 2020 by the authors. Licensee MDPI, Basel, Switzerland. This article is an open access article distributed under the terms and conditions of the Creative Commons Attribution (CC BY) license (http://creativecommons.org/licenses/by/4.0/). 